\title{
كفاءة خدمات المراكز الصحية في مدينة الحلة \\ (باستخدام تقنية نظم المعلومات الجغرافية (GIS)
}

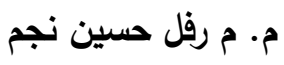

د. م. ميرة محمد علي حمزة الأسدي

Ameera-alasdi@yahoo.com

\section{المستخلص:}

تناولت العديد من البحوث والدراسات أهية تخطيط الخدمات في المدينة بثكل رئيسي لتطوير البيئة الحضرية ونموها , اذ لابد من توفير الحد الأدنى من هذه الخدمات والتي تعتبر موطن الاستقرار للسكان

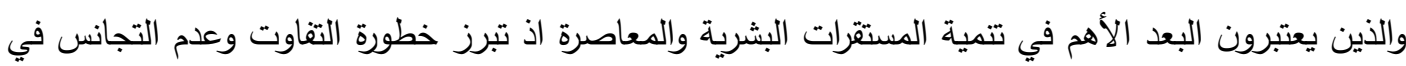

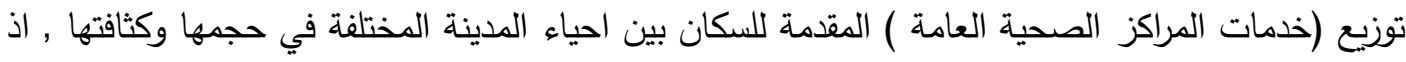

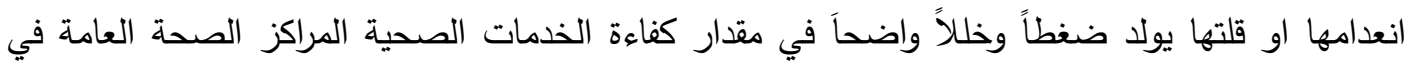
الأحياء الأخرى • يتطرق هذا البحث الى دراسة كفاءة خدمات المراكز الصحية العامة وكفايتها في مدينة

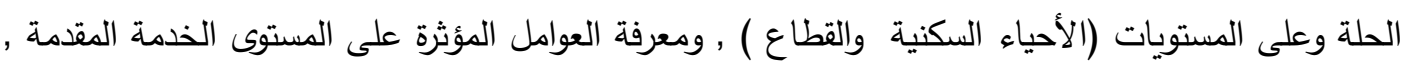

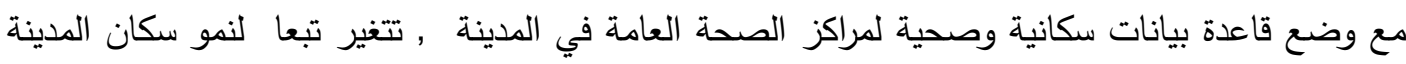

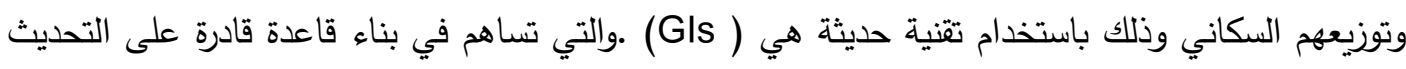

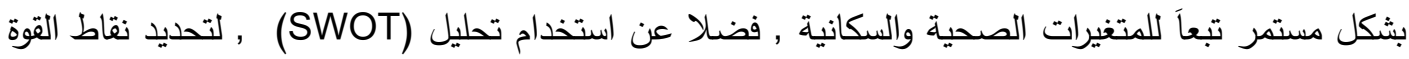
ونقاط الضعف والتهديدات والفرض لقطاع المراكز الصحية العامة في مدينة الحلة. 
ABSTRACT:

Several researches and studies have dealt with the importance of planning services in the city mainly to develop the urban environment and its growth. It is necessary to provide the minimum of these services, which is considered the home of stability for the population and which are considered the most important dimension in the development of human and contemporary stability. Public health centers) provided to the population among the different neighborhoods of the city in size and density, as the lack or decrease creates pressure and a clear imbalance in the efficiency of health services centers of public health in other neighbor This study investigates the efficiency and adequacy of public health centers' services in the city of Hilla and on the levels of residential neighborhoods and the sector, and the factors affecting the level of service provided, with the development of a population and health database for public health centers in the city. Using a modern technology (GIs) that contribute to building a base that can be continuously updated according to health and population variables, as well as using SWOT analysis to identify the strengths, weaknesses, threats and imposition of the public health centers sector in Hilla.

حظي الجانب الصحي باهتمام واسع على النطاق الإقليمي والحضري , لما له من أثر واضح على التتمية

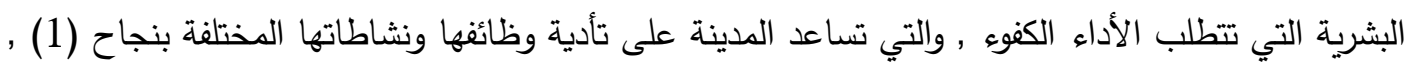

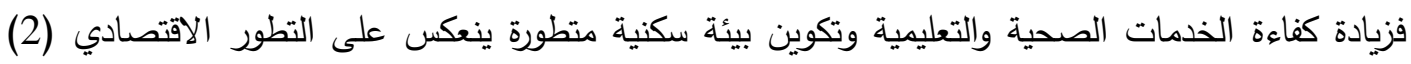

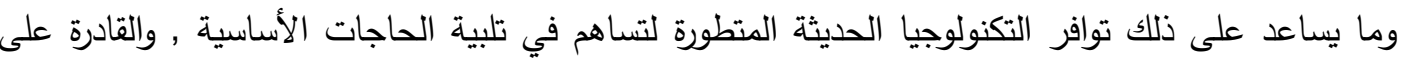

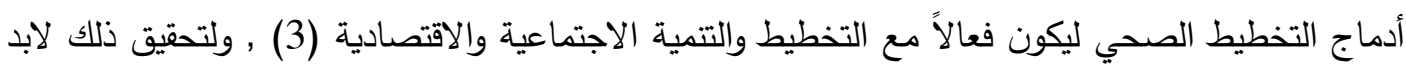

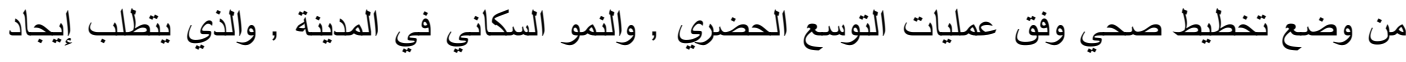

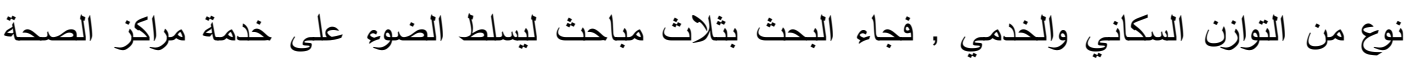
العامة في المدينة , والتي تعد النواة الطبية الاولى حيث تجاء تقدم خدماتها على مستوى الاحياء والمحلات

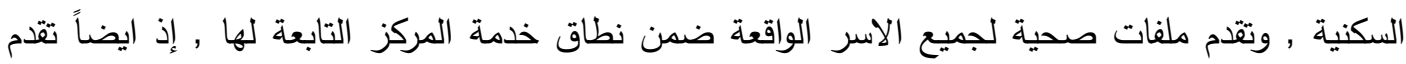
خدمات علاجية ووقائية , وتحويل الحالات التي يتعذر معالجتها الى المراكز الدتخصصة عند اللزوم , 
المبحث الاول تضمن معرفة العوامل ( الموقع والموضع ) والتي تؤثر على صحة الانسان , المبحث

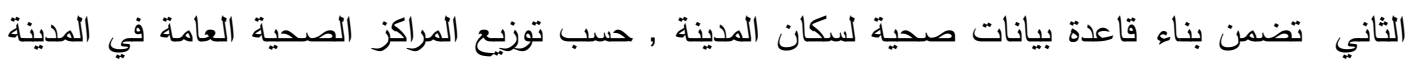

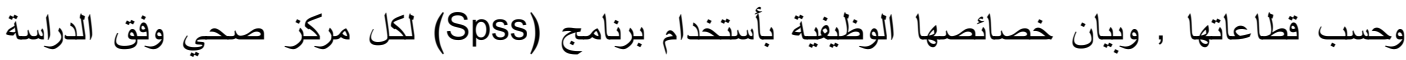
الميدانية لعام 2016/2015 , اما المبحث الثالث تضمن قياس كفاءة خدمات مراكز الصحة العامة وفق باست معايير بشرية , ومعايير مكانية (سهولة الوصول - زمن الوصول - وسيلة الوصول ) ومعايير اجتماعية

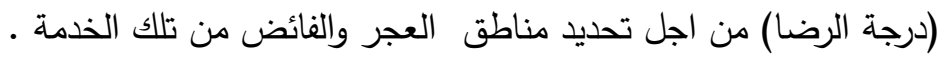

أذ شهدت المعرفة الجغرافية لاسيما التطبيقية تطوراً مع ظهور تقنية (Gls) اذ لها امكانية عالية على التحليل الدكاني (Spatial Analysis) ومن هنا جاءت الاهمية في توظيف هذه التقنية وبتحليل التوزيع المكاني

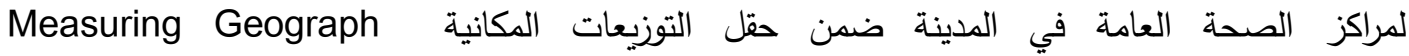

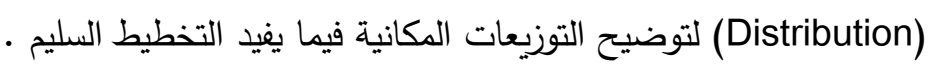

مشكلة البحث : شهدت مدينة الحلة تطوراً ونمواً كبيرين خلال السنوات الاخيرة , وهذا التطور والنمو لم يرافقه

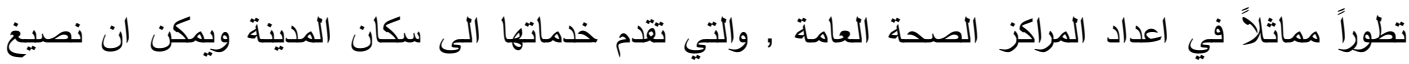

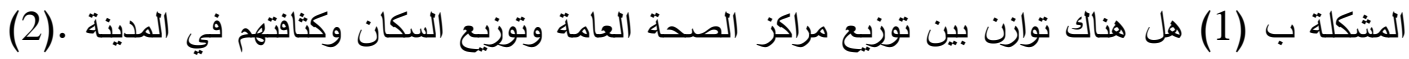
هل يخضع توزيع مراكز الصحة العامة وللمعايير الصحية المحلية من حيث الكفاءة والكفاية .

"تم تغير التسمية في عموم العراق , وزارة الصحة , ادارة الصحة العامة , العدد (29837) بتاريخ 17/ 2008/6, وتبنت بموجبه تغير اسم قسم الرعاية الصحية الاولية الى قسم الصحة العامة . 
فرضية البحث : (1) تتوزع مراكز الصحة العامة بثكل يتناسب مع حجم السكان في احياء المدينة ,

(2) هناك تباين في كفاءة وكفاية مراكز الصحة العامة وتوزيعها , ولم يكن وفق معايير الصحة المحلية .

هدف البحث :. 1- معرفة كفاءة خدمات مراكز الصحة العامة في احياء وقطاعات الددينة . 2- اعداد قاعدة بيانات صحية وسكانية للمراكز الصحة العامة باستخدام (Gls).

3- تطبيق معايير لهعرفة كفاءة وكفاية خدمة المراكز الصحية العامة .

4- تحديد نمط توزيع مراكز الصحة العامة .

أهمية البحث : 1- تعاظم اهية قطاع الخدمات العامة ( publici saves) بشكل عام والخدمات الصحية على وجه الخصوص لكون خدماتها تقدم لعدد كبير من سكان المدينة , فضلا عن (service shealth )

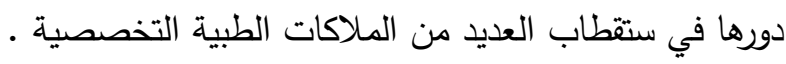

2- عدم وجود دراسة متخصصة بخدمات المراكز الصحية العامة ـ وكفاءتها الوظيفية في المدينة .

3- أهمية بناء قاعدة بيانات صحية وسكانية ومعرفة دورها في تحقيق التتمية الاجتماعية والاقتصادية .

الحدود المكانية والزمانية للبحث :. تشمل الحدود المكانية مدينة الحلة وفق التقييم الاساس (2006-2030) والتي تتكون من اربع قطاعات قطاع (الفردوس) الذي يمثل الصوب الصغير (الجانب الشرقي) من الددينة

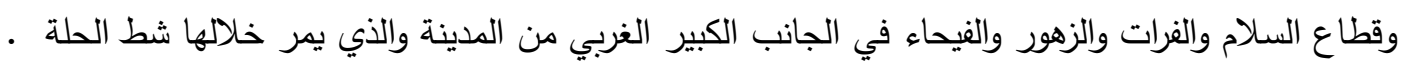
بلغ عدد سكان المدينة عام ( 2015) , (452875) نسمة وبنسبة (77\%) من سكان مراكز الحلة البالغ

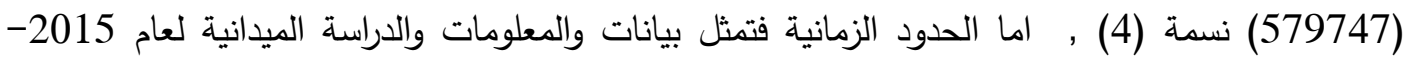

منهج البحث : اعتمدت الباحثين على المنهج الوصفي من اجل التعرف على الظاهرة المدروسة , والمنهج التحليلي الكمي معززاً بالدراسة التطبيقية لواقع وكفاءة خدمات مراكز الصحة العامة , بغية تحديد اهم 
خصائص الوظيفية للخدمة معتمدا على استخدام البرنامج الاحصائي ( Spss) , ونظم المعلومات الجغرافية لتحديد نطاق الخدمة , بناء قاعدة بيانات سكانية صحية للمراكز الصحة العامة في المدينة .

عينة البحث : تطلب البحث اعداد استمارة استبانة تضمنت (21) سؤال تم توزيعها على المراجعين الى الى العي المراكز الصحة العامة , واخرى لمدراء المراكز الصحية العامة , وذلك لمعرفة الخصائص الوظيفية لخدمة

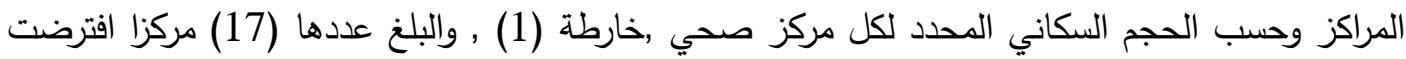
الباحثين ان كل استمارة تمثل (500) شخص , فكان مجموع الاستمارات (906) استمارة , وكان نصيب كل

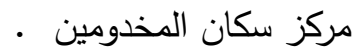
جدول (1) اسماء المراكز الصحة العامة وحجم العينة حسب الحجم السكاني :

\begin{tabular}{|c|c|c|c|c|}
\hline عدد الاستمارات & نسبة المئوية للسكان \% & عدد السكان المذذومين & أسم المركز & ت \\
\hline 9 & 1 & 5955 & م.ص" المركز & 1 \\
\hline 100 & 11 & 50509 & م.ص الباقر م. ل م. & 2 \\
\hline 82 & 9 & 40778 & م.ص الخالصة & 3 \\
\hline 54 & 6 & 26611 & م.ص مرجان & 4 \\
\hline 72 & 8 & 37437 & م.ص وردية خارج & 5 \\
\hline 82 & 9 & 41094 & م.ص القاضية & 6 \\
\hline 91 & 10 & 45833 & م.ص بابل التلريبي & 7 \\
\hline 36 & 4 & 12231 & م.ص الكوثر & 8 \\
\hline 36 & 4 & 13194 & م.ص النهضة & 9 \\
\hline 91 & 10 & 47140 & م. ص شهاء نادر & 10 \\
\hline 100 & 11 & 50685 & م.ص الزهراء & 11 \\
\hline 27 & 3 & 10955 & - م.ص الاساتذة النموذجي & 12 \\
\hline 9 & 1 & 5000 & م.ص حي الامام النموذجي & 13 \\
\hline 18 & 2 & 10955 & - م.ص المهنسين & 14 \\
\hline 18 & 2 & 10955 & م.ص شهيد الاسلام & 15 \\
\hline 18 & 2 & 9798 & م.ص القسس & 16 \\
\hline 63 & 7 & 33746 & م.ص الهادي & 17 \\
\hline 906 & 100 & 452875 & المجموع - ل المع & 1 \\
\hline
\end{tabular}

الصصدر : من عمل الباحثتين بالاعتماد على بيانات مديرية صحة بابل , شعبة (مراكز الصحة العامة ) التحصين , (النفوس واهداف الخاصة بالبرنامج الموسع للتحصين ) , قطاع الحلة الاول وقطاع الحلة الثاني , لعام 2016, بيانات غير منشورة .

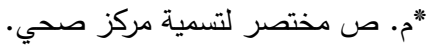


هنالك بعض المفاهيم التي ترتبط بموضوع البحث ومنها:

1-مفهوم الصحة العامة (public Health) وتعرفها منظمة الصحة العالمية (ان الصحة حالة من الكفاية البدنية والعقلية والاجتماعية وليست مجرد عجز او خلو من الامراض (6) اما وزارة الصحة العراقية تعرفها (توفر التأمين الصحي للمجتمع لضمان تقليل معدلات الامراض وحجم الوفيات واستدامة المجتمع، وتزويد السكان بالخدمة بأفضل كمية ونوعية من خلال (المؤسسات الصحية)(7). 2-الخدمات الصحية (Sanitary Services) كافة الخدمات المقدمة للوقاية من اخطار الامراض ومما يعتري ذلك من متطلبات ادارية وفنية وطبية تساهم في الوقاية من المرض , وان

خريطة (1)

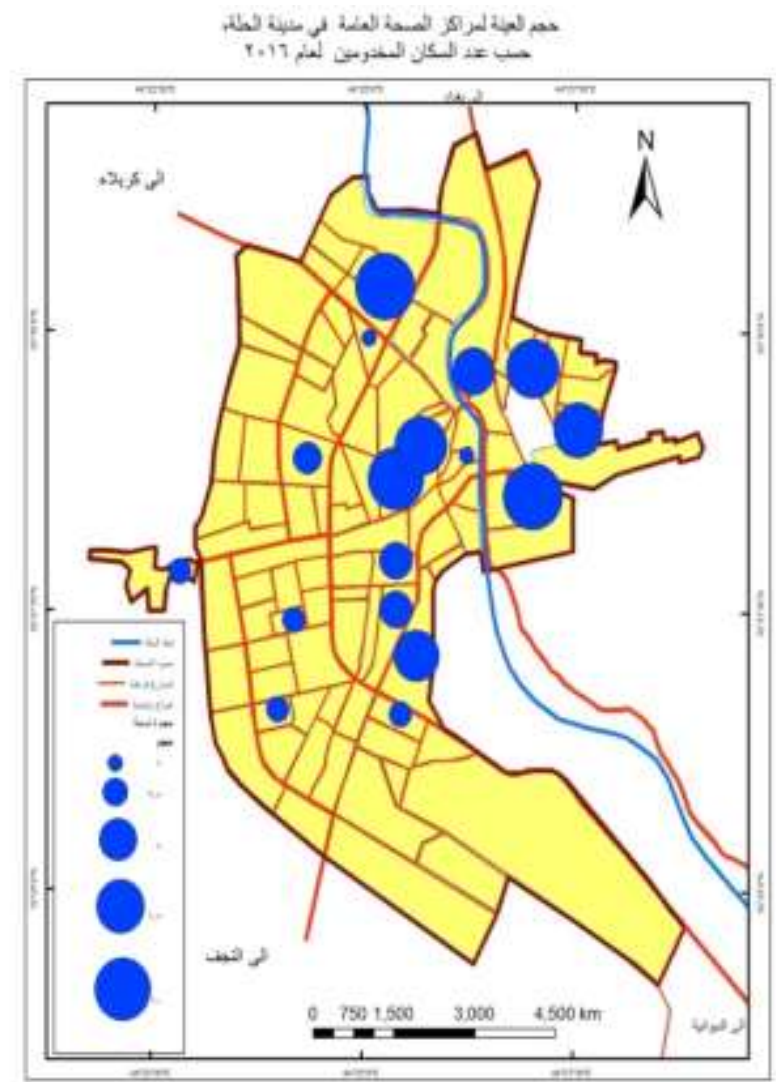

المصدر : من عمل الباحثين بالاعتماد على جدول(1). 
المؤسسات الصحية على اختلاف انواعها كالمراكز الصحية والعيادات الخاصة والمستشفيات هي المسؤولة

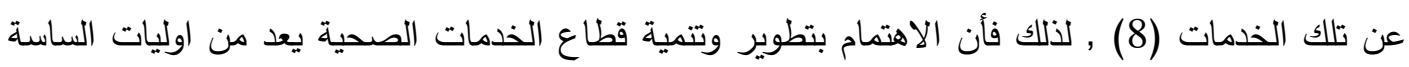

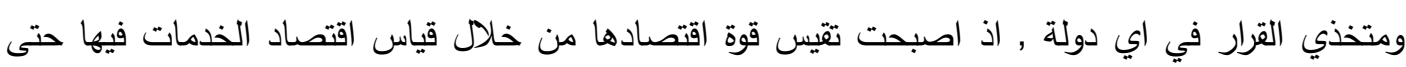
وصلت في الولايات المتحدة اكثر من نصف الناتج دولة الاجمالي للدولة (9).

3 - الكفاءة Efficiency) تعرف الكفاءة في الدراسات الجغرافية بأنها الكيفية التي يتم بها استخدام

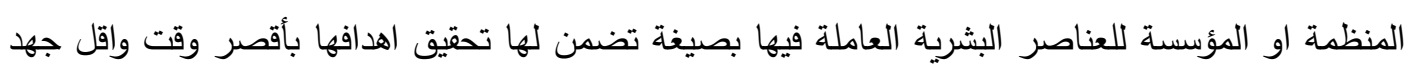

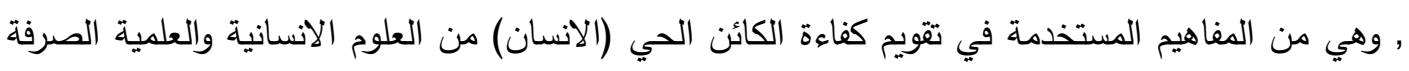

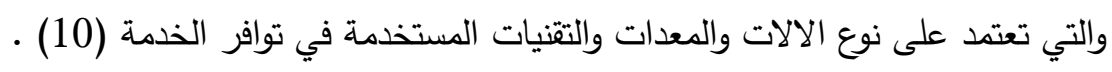

4- نظم المعلومات الحغرافية : ( Geographical information system ) وهي تقنية حديثة تسهم في احداث تطور علمي في محتلف المجالات , ولاسيما في الدراسات الجغرافية كأداة لجمع المعلومات وخزنها ومعالجتها وتحليلها وعرضها بصورة مختلفة (11).

حسب نوعية وهدف الدراسة , وتتعامل مع الخريطة بأسلوب ديناميكي حيث تسهم في عرض العالم لجغرافية

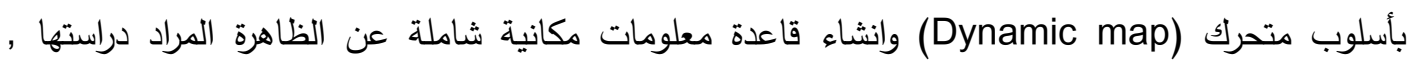

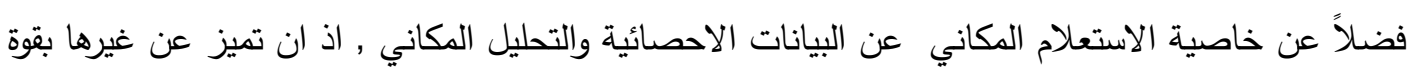

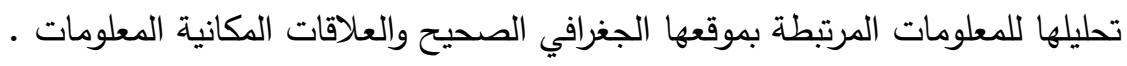

5- الكفاءة المكانية : يقصد بها كفاءة التوزيع من حيث سهولة الوصول وتهيئة الخدمات التي تسهم بدرجة عالية في تثكيل معايير نظام المدينة , لاسيما عندما يكون ذلك الففهوم محدوداً انماط التقاعل المكاني (12) (12)

هيكلية البحث: تضمن البحث ثلاث مباحث , الاول تطرق الى خصائص الموقع والموضع لمدينة الحلة ,

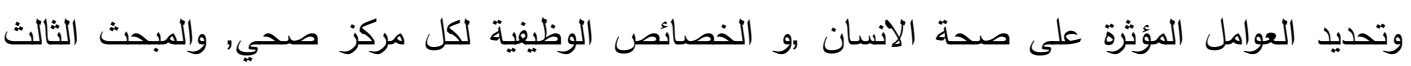
تضمن قياس كفاءة وكفاية مراكز الصحة العامة , في قطاعات واحياء المدينة , وتلخص البحث بعدد من لاند 
الاستتتاجات والتوصيات الخاصة بموضوع الدراسة , محاولة لتحديد ومعرفة الاحياء التي تتوافر فيها الخدمة

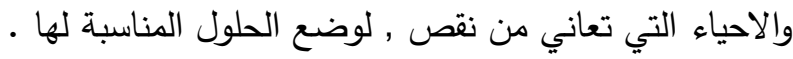
المبحث الاول : الخصائص الجغر افية لمدينة الحلة :

الموقع والموضع ( Astronrical location )

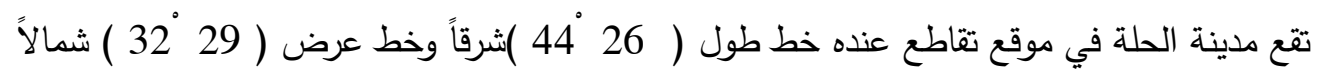
, وموقع جغرافي للأقاليم المجاورة ( Situatio) , اذ تمثل مدينة الحلة المركز الاداري لمحافظة بابل ,

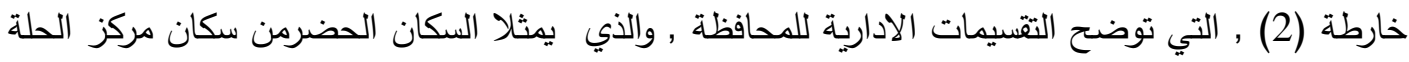

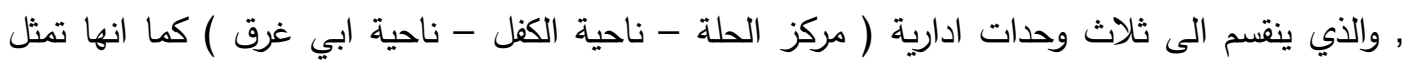

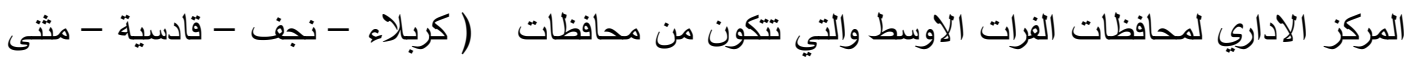
) ) : اذ ترتبط معها بعلاقات وظيفية متبادلة ساهمت في نمو المدينة وتطورها (13). ت تبلغ مساحة مدينة الحلة ( 5681) هكتارا وبنسبة (34\%) من مساحة مركز الحلة والذي تبلغ مساحته (16709 (168) ) هكتارا , وتضم

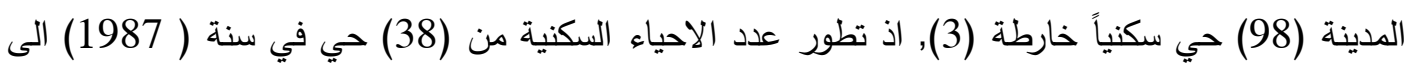
(60) حي سنة 1997, ليصل الى (62) حي سنة (2002) , حيث وضعت بلدية الحلة الحنة ترتيباً قطاعياً للددينة الى اربع قطاعات ( قطاع الفردوس) ويحمل (1) , قطاع الفيحاء يحمل الرقم (2) و قطاع السلام

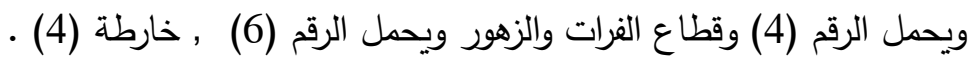

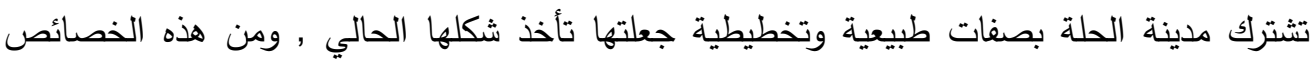
والصفات الطبيعية التي تتؤثر على صحة الانسان ونشاطه في المدينة , وتتمثل بالعوامل اولا : العوامل الطبيعية الطبي وتمثلت : 1- المناخ : يعد من العوامل الطبيعية المؤثرة على صحة الانسان ونشاطه وفعالياته المختلفة رواسلوب حياته

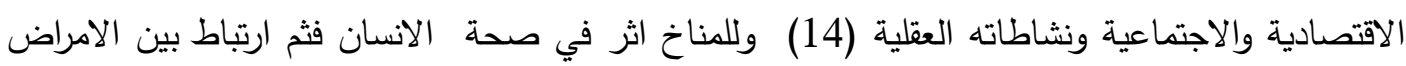

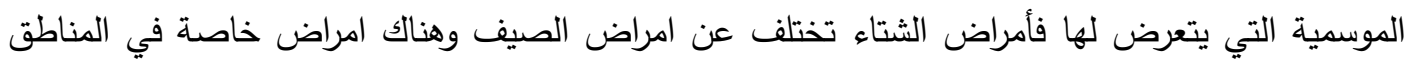

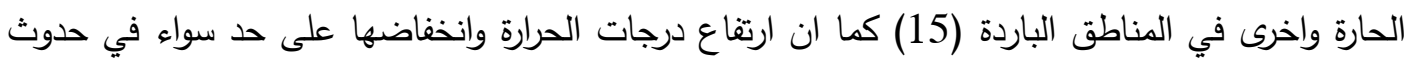

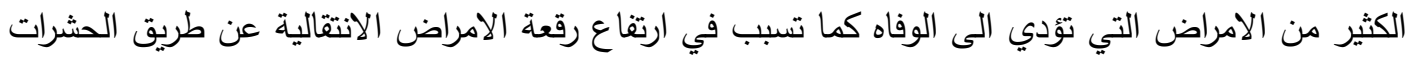


ويظهر تأثير المناخ في المسافة , اي من خلال مسافة السير بين الوحدات السكنية وموقع المراكز

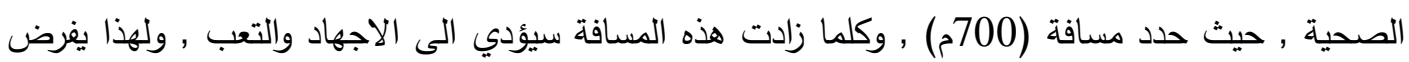

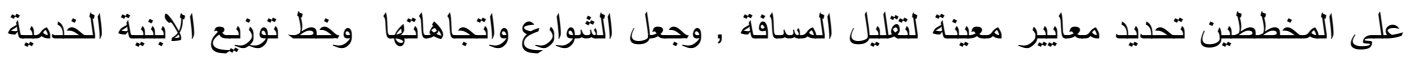
ولصحية منها , وحجم الفضاءات المفتوحة ونوعية الطلاء المستخدم في اكساء واجهات الابنية (17) , أن الن النائل

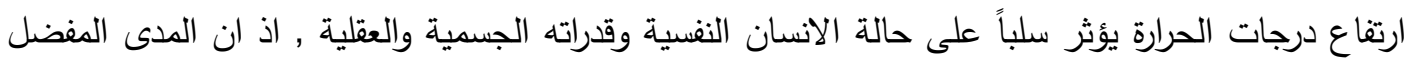

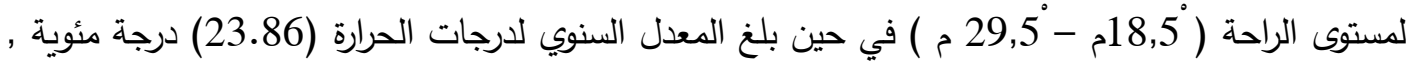

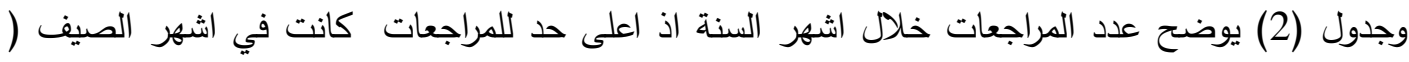

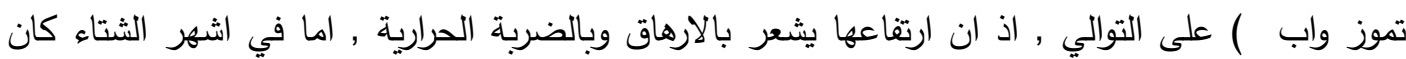

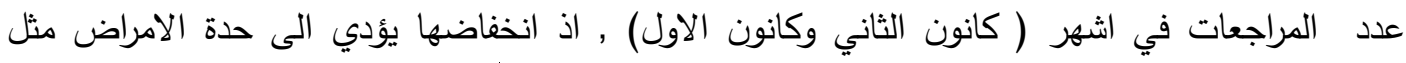

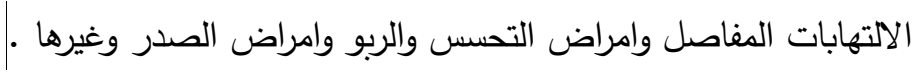



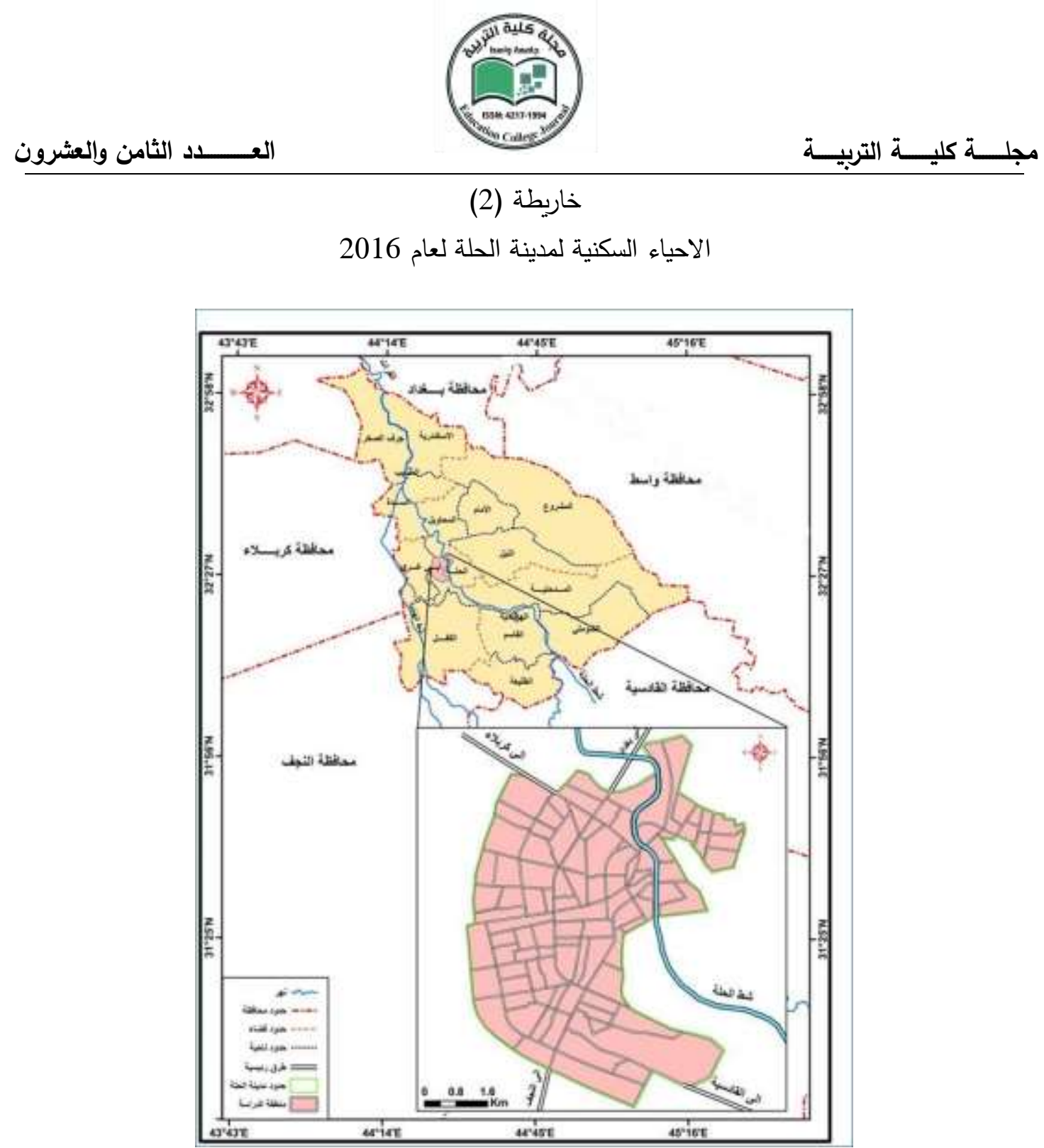

المصدر / جمهورية العراق ، الهيأة العامة للمساحة ,قسم انتاج الخرائط,خارطة محافظة بابل الادارية,2015. 


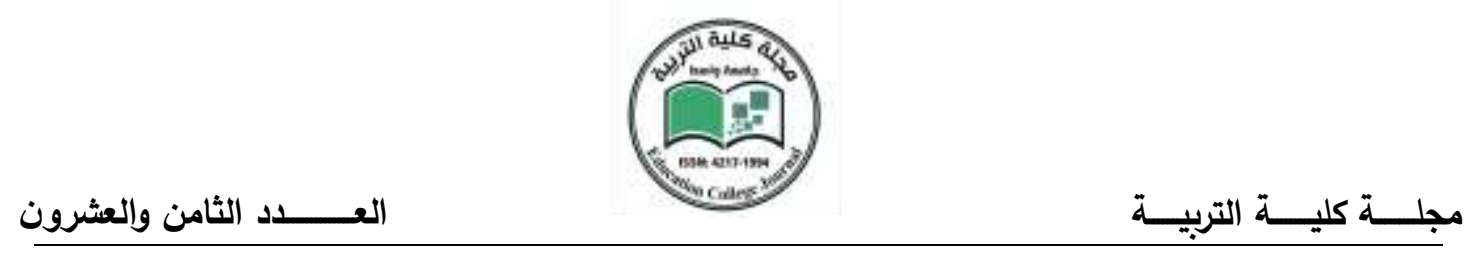

خريطة (3) كنة (3)

الأحياء السكنية لمدينة الحلة لعام 2016

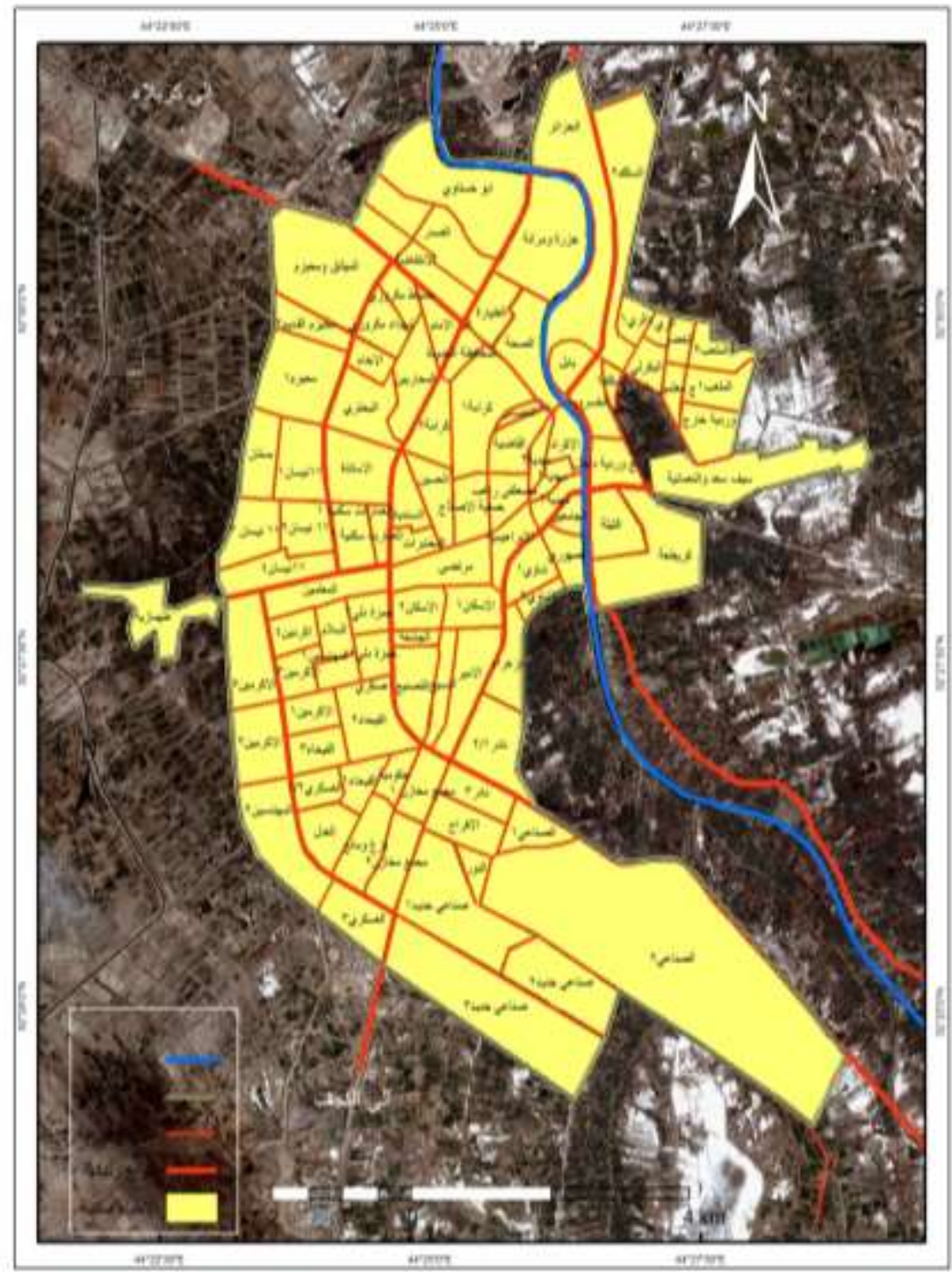

المصدر / من عمل الباحثتين بالاعتماد على خرائط ، الهيأة العامة للمساحة ,قسم انتاج الخرائط,خارطة الاحياء السكنية

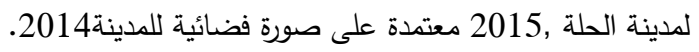




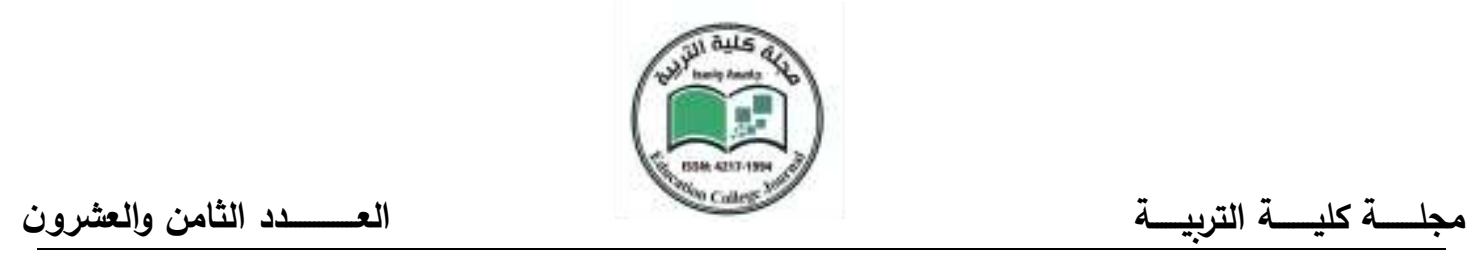

خريطة (4)

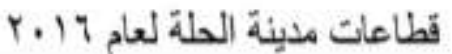

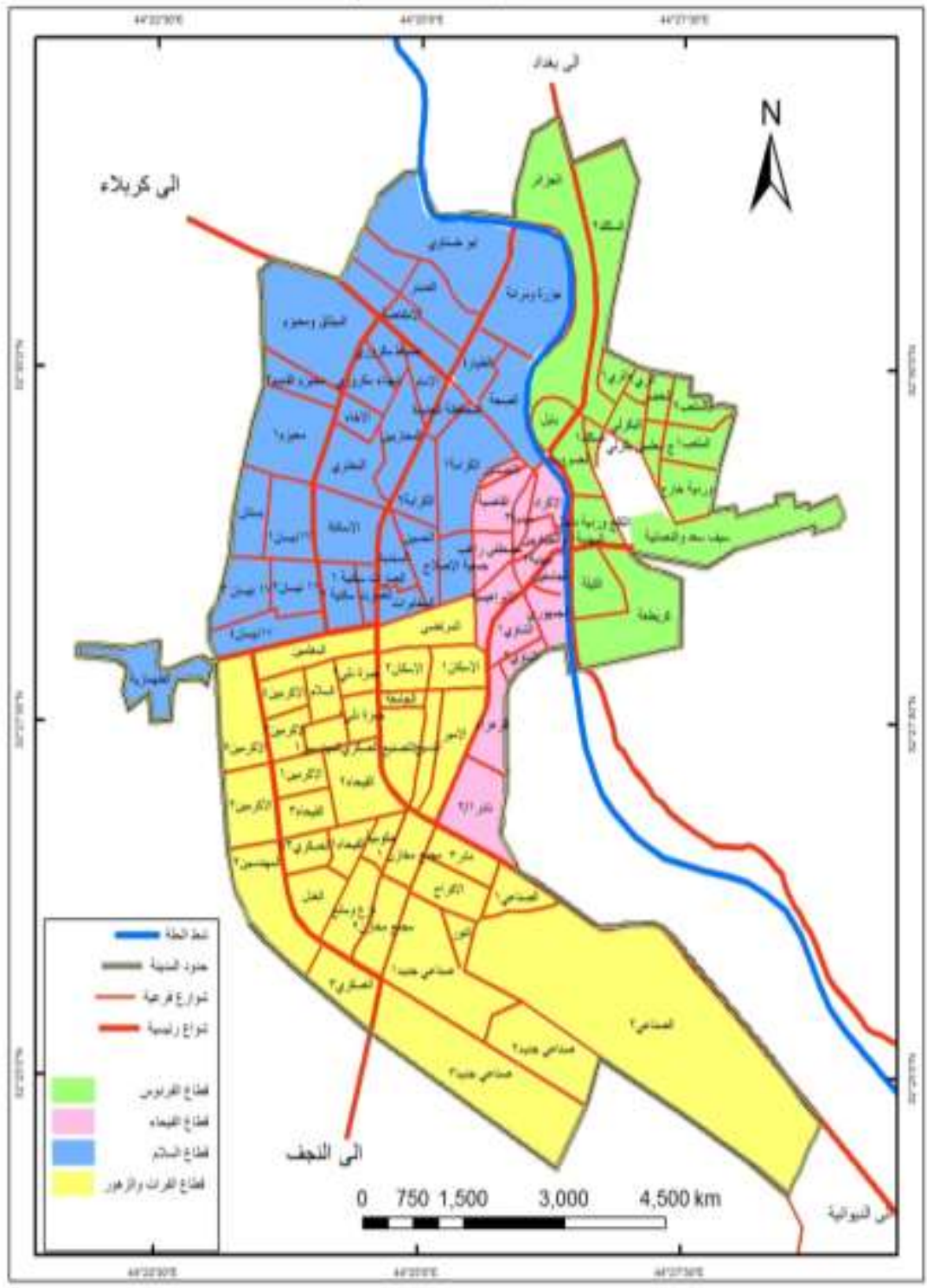

المصدر / من عمل الباحثين بالاعتماد على خارطة القطاعات , مديرية بلدية الحلة , قسم الاملاك , 2015 


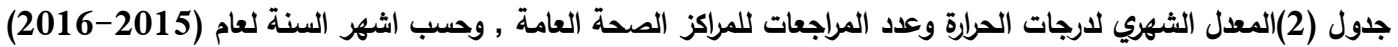

\begin{tabular}{|c|c|c|c|c|c|c|c|c|c|c|c|c|c|}
\hline كانون 1 & تشرين2 & تشرين 1 & ايلول & اب & تموز & حزيان & مايس & نيسان & اذار & شباط & كانون 2 & المركز & القطاع \\
\hline 12,58 & 18,25 & 26.09 & 31.33 & 34.96 & 34.89 & 33.19 & 29.35 & 23.73 & 17.93 & 13.31 & 10.8 & \multicolumn{2}{|c|}{ 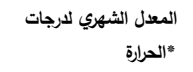 } \\
\hline 3880 & 4636 & 4323 & 4078 & 4753 & 4950 & 4176 & 4726 & 5409 & 5758 & 5640 & 6004 & 1-الباقر & الفردوس \\
\hline 2989 & 3985 & 3794 & 3794 & 4764 & 4294 & 3489 & 4167 & 5528 & 5354 & 4948 & 5372 & -2 & \\
\hline 4192 & 4633 & 4794 & 4720 & 5333 & 5839 & 4635 & 4230 & 5730 & 5053 & 4909 & 6402 & الخالصة & \\
\hline 4350 & 3687 & 3675 & 3060 & 3274 & 3010 & 2729 & 3625 & 3194 & 3480 & 2943 & 4550 & 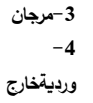 & \\
\hline 6613 & 4919 & 4921 & 5275 & 6304 & 5427 & 4872 & 2822 & 6360 & 6123 & 6148 & 5101 & 1-|المركز & الفيحاء \\
\hline 3089 & 4194 & 3477 & 3996 & 4690 & 1968 & 3885 & 4660 & 5476 & 5315 & 6257 & 2788 & -2 & \\
\hline 8981 & 7035 & 5955 & 6496 & 8250 & 8495 & 8572 & 7910 & 8795 & 8063 & 7677 & 9571 & 3 القاضية & \\
\hline 2156 & 5454 & 2199 & 4018 & 5618 & 2228 & 3820 & 1954 & 2870 & 2158 & 4081 & 3165 & 1- الزهراء & قضاء \\
\hline 2152 & 2877 & 3831 & 7154 & 4614 & 5225 & 6821 & 2111 & 5441 & 2261 & 5222 & 5421 & 2-القسس & السلام \\
\hline 2321 & 2522 & 3215 & 4128 & 6144 & 5512 & 4181 & 3181 & 6543 & 2521 & 2354 & 3242 & 3-بابل & \\
\hline 4224 & 1312 & 4120 & 7181 & 6122 & 5121 & 5112 & 3121 & 2823 & 4125 & 1263 & 2512 & -4 & \\
\hline 4530 & 3817 & 5914 & 4332 & 5787 & 5607 & 4258 & 6541 & 3632 & 3544 & 5431 & 5421 & 5 الاستذة & \\
\hline 1288 & 1647 & 1797 & 1150 & 1795 & 1470 & 1780 & 2468 & 1970 & 2397 & 2324 & 2825 & 1-الكوثر & الفرات \\
\hline 1960 & 2381 & 2348 & 1920 & 2111 & 1193 & 1626 & 1967 & 2293 & 2421 & 2397 & 3981 & -2 & والزهور \\
\hline 6669 & 6110 & 6148 & 5654 & 5400 & 5154 & 5952 & 4796 & 5648 & 6610 & 6516 & 7389 & 3- شهاء & \\
\hline 3878 & 3785 & 4253 & 3028 & 5122 & 4661 & 4215 & 3260 & 2784 & 5642 & 3251 & 6120 & نادر3 & \\
\hline 2154 & 5812 & 3284 & 3299 & 3465 & 3878 & 3670 & 2551 & 3165 & 4125 & 5282 & 5243 & 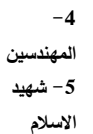 & \\
\hline 80837 & 68815 & 68048 & 73283 & 78320 & 78379 & 53793 & 63090 & 77660 & 74977 & 71643 & 81507 & المجموع & \\
\hline 9 & 8 & 8 & 9 & 9 & 9 & 6 & 7 & 9 & 9 & 8 & 9 & نسبة \% & \\
\hline
\end{tabular}

المصدر: * بالاعتماد على :1- محطة الحلة المناخية, للمدة 1989-2015 بيانات غير منشورة , 2- مديرية صحة بابل, بيانات غير منشورة , قسم مراكز الصحة العامة (2016/2015) بيانات غير منشورة . 
وتوصلت الدراسة (نتائج الاستبانة ) ان(41\%) في اشهر الشتاء من المراجعيين يتأثرون بانخفاض درجات

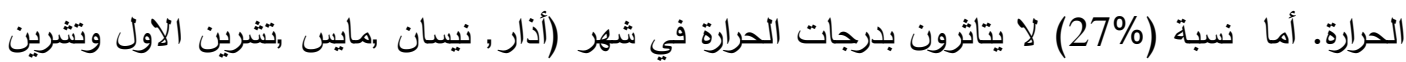

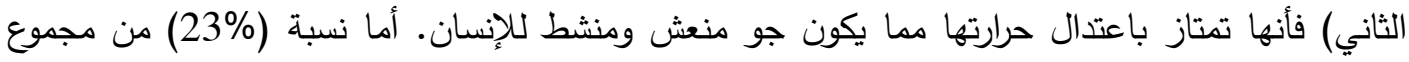
المراجعيين يتأثرون في اشهر (حزيران ,تموز , آب وايلول) اذ تكون الحرارة مرتفعة (18), وبذلك تكون درجة

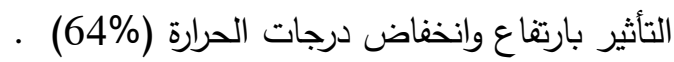

شكل (1) معدلات الحرارة الثهرية في محطة الحلة للمدة من (2015-1989)

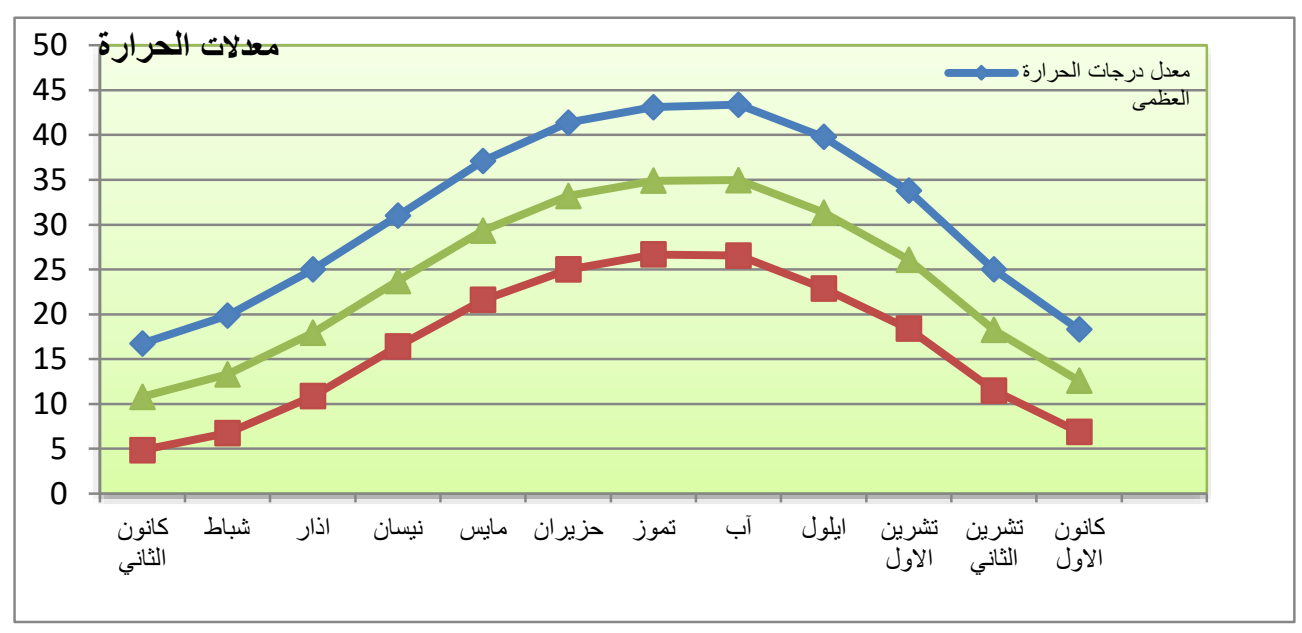

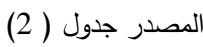

الرياح : وهي وسيلة تعمل على نقل الطاقة الحرارية وبخار الماء وما ينتج عنها من تغيرات في الظواهر الجوية من منطقة لأخرى (19) • وأن الرياح السائدة في مدينة الحلة هي (الثمالية الغربية ,الغربية والثمالية) البالغ نسبة هبوبها (25.4, 19.5, 16.4)على التوالي من نسبة هبوب الرئ الرياح في منطقة الدراسة.

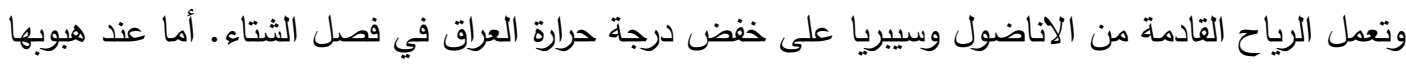
في فصل الصيف تعمل على تخفيف حرارة هذا الفصل وتلطف الجو . أما الرياح (الجنوبية الثرقية , الجنوبية والجنوبية الغربية) البالغ نسبة هبوبها (7.8 , 3.4 , 2.2) على التوالي, تعد رياح دافئة رطبه في الثتاء

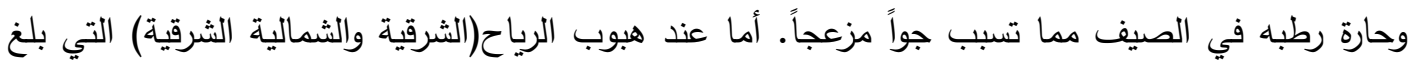


نسبة هبوبها (5.6 , 3.4)على التوالي فأنها تسبب انخفاضاً شديداً في درجة حرارة الثتاء وتخفف من حرارة

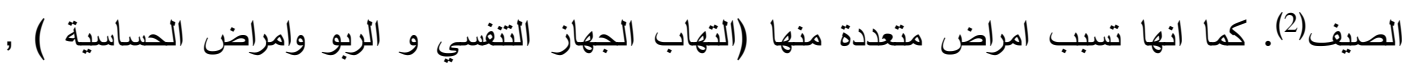

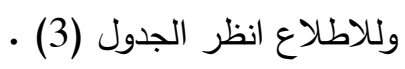

جدول (3) النسب المئوية لاتجاهات الرياح السائدة في محطة الحلة للمدة (2015-1989)

\begin{tabular}{|c|c|c|c|c|c|c|c|c|c|c|}
\hline المجموع & السكون & شربية & غربية & غنوبية & جنوبية & شرقوبية & شرقية & شرقية & شمالية & اتجاه الرياح \\
\hline$\% 100$ & 16.3 & 25.4 & 19.5 & 2.2 & 3.4 & 7.8 & 5.6 & 3.4 & 16.4 & النسبة المئوية \\
\hline
\end{tabular}

المصدر: محطة الحلة المناخية بيانات غير منشورة, 2015.

و لها علاقة واضحة بصحة الانسان وتختلف حسب صفاتها وسرعتها فقد تزيد من الفقدان الحراري , ونان

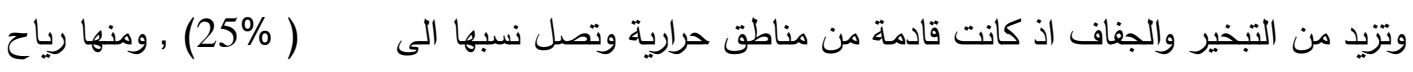

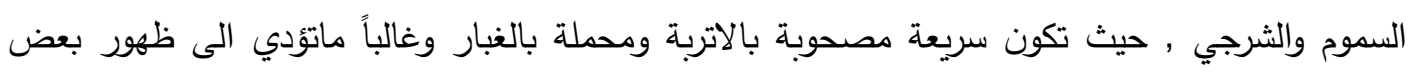

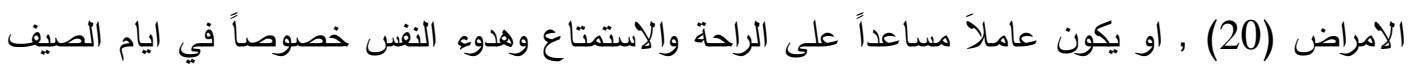

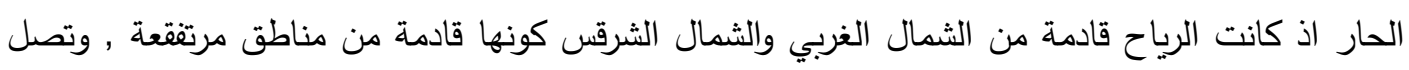

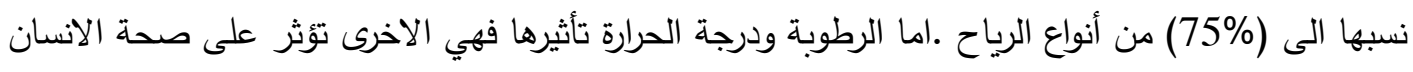

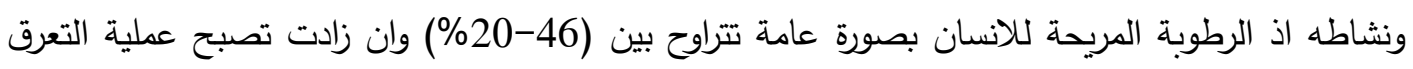
عملية صعبة بسبب تثبع الهواء بالبخار مما يؤدي في الصيف الى عدم الارتياح (21) , وتختلف تلفان الأمطار

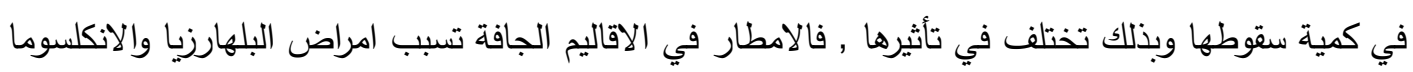

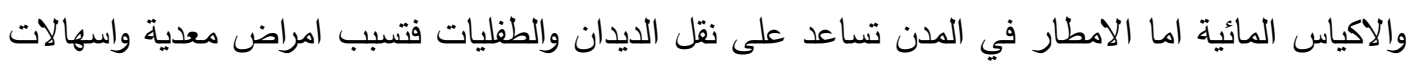

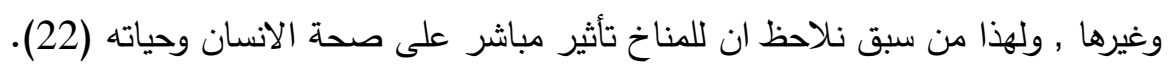

2- العوامل البشرية : لاتقل اهمية في تأثيرها على الانسان وكيفية تقديم وتوفير الخدمة له , فالانسان هو

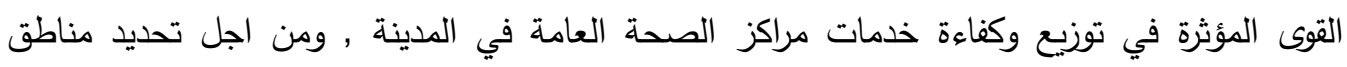
النقص والفائض من هذه الخدمة , سيتم التطرق الى :

1- توزيع السكان : يتباين توزيع السكان في المدينة , ويشمل السكان القاطنين في احيائها ومناطقها , ودراسة الفائ

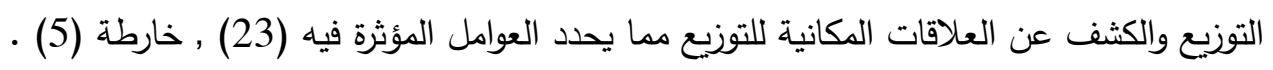


جدول(4) عدد سكان مدينة الحلة, حسب الاحياء السكنية ونسب قطاعاتها لعام 2016.

\begin{tabular}{|c|c|c|c|c|c|c|c|}
\hline$\%$ & عدد السكان & اسم الحي & $ت$ & $\%$ & عدد السكان & اسم الحي & $ت$ \\
\hline & & قطاع الفيحاء & & & & قطاع الفردوس & \\
\hline & 5067 & الجامعيين وجديدة & 1 & & 1496 & بابل & 1 \\
\hline & 5559 & الجمهوري & 2 & & 2828 & الخسروية & 2 \\
\hline & 4510 & المهدية1 & 3 & & 3924 & الجزائر & 3 \\
\hline & 3905 & المهدية2 & 4 & & 3225 & الكلج & 4 \\
\hline & 1167 & مهرية3 & 5 & & 1914 & الثيلة & 5 \\
\hline & 10178 & الثاوي 1 & 6 & & 5406 & كريطعة & 6 \\
\hline & 3498 & 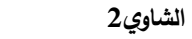 & 7 & & 584 & 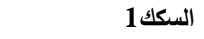 & 7 \\
\hline & 6642 & الكراد & 8 & & 4982 & السكك 2 & 8 \\
\hline & 6310 & 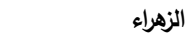 & 9 & & 4706 & الري1 & 9 \\
\hline & 11381 & 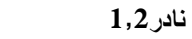 & 10 & & 2266 & 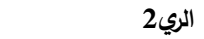 & 10 \\
\hline & 4310 & الابراهيمية & 11 & & 12192 & سيف سعد والنعمانية & 13 \\
\hline & 4740 & مصطفى راغب & 12 & & 3401 & وردية داخل & 14 \\
\hline & 6251 & القاضية & 13 & & 7720 & جمعية معلمين بكرلي & 15 \\
\hline 16 & 73518 & المجموع & & & 14434 & ملعب 1 & 16 \\
\hline & & & & & 1474 & ملعب2 - مل مل & 17 \\
\hline & & & & & 7476 & الخضر & 18 \\
\hline$\%$ & ع عدد السكان & قطاع الفرات والزههور & & 14 & 65038 & 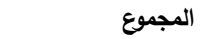 & \\
\hline & 3075 & فزع ومانع & 18 & $\%$ & عدد السكان & قطاع السلام & ت \\
\hline & 4077 & الفيحاء 1 & 19 & & 3351 & جمعية الاصلاح & 1 \\
\hline & 4906 & الفيحاء 2 & 20 & & 8322 & الكرامة 1 & 2 \\
\hline & 6130 & الفيحاء 3 & 21 & & 1831 & الكرامة 2 & 3 \\
\hline & 4789 & العسكري 1 & 22 & & 5605 & الحسين & 4 \\
\hline & 253 & العسكري2 & 23 & & 3748 & 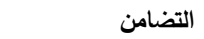 & 5 \\
\hline & 5794 & العسكري3 & 24 & & 2980 & السندباد & 6 \\
\hline & 4893 & المهنسين 1 & 25 & & 2622 & المخابرات & 7 \\
\hline & 4457 & المهنسين2 & 26 & & 140 & المحافظة الجديدة & 8 \\
\hline & 8029 & العدل ل & 27 & & 9330 & الاساتذة & 9 \\
\hline & 6748 & الاكرمين 1 & 28 & & 3033 & الصحة & 10 \\
\hline & 9061 & الاكرمين2 & 29 & & 3354 & العماراتالسكنية 1 & 11 \\
\hline & 4692 & الاكرمين3 & 30 & & 8445 & العمارات السكنية2 & 12 \\
\hline & 5693 & الاكرمين4 & 31 & & 4972 & الطيارة & 13 \\
\hline & 5680 & الاكرمين5 & 32 & & 2781 & 17 17نيسان 1 & 14 \\
\hline & 7419 & السلام & 33 & & 5043 & 17نيسان2 & 15 \\
\hline & 9412 & المعلمين & 34 & & 2354 & 17نيسان3 & 16 \\
\hline
\end{tabular}


العــــــــد الثامن والعشرون

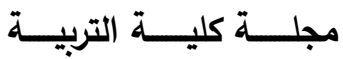

\begin{tabular}{|c|c|c|c|c|c|c|c|}
\hline & 722 & حمزة الدلي1 & 35 & & 5088 & 17نيسان4 & 17 \\
\hline & 4469 & حمزة الدلي2 & 36 & & 4100 & جزة ومرانة & 18 \\
\hline 34 & 154226 & المجموع & & & 11497 & محاربين & 19 \\
\hline \multirow[t]{31}{*}{100} & 452875 & مجموع المدينة & & & 576 & البستان & 20 \\
\hline & & & & & 2663 & البحتري & 21 \\
\hline & & & & & 5064 & الامام & 22 \\
\hline & & & & & 4444 & الاخاء & 23 \\
\hline & & & & & 6987 & الشهاء مكروري & 24 \\
\hline & & & & & 11253 & الطهمازية /14 & 25 \\
\hline & & & & & 3818 & الانتفاضة & 26 \\
\hline & & & & & 2132 & الصدر & 27 \\
\hline & & & & & 2102 & محيزم 1 & 28 \\
\hline & & & & & 269 & محيزم 2 & 29 \\
\hline & & & & & 4021 & الميثاق & 30 \\
\hline & & & & & 5291 & ابو خستاوي وزوير & 31 \\
\hline & & & & 35 & 160093 & المجموع & \\
\hline & & & & $\%$ & عدد السكان & قطاع الفرات والزهور & \\
\hline & & & & & 8149 & نادر3 & 1 \\
\hline & & & & & 5043 & الامير & 2 \\
\hline & & & & & 7379 & الافراح & 3 \\
\hline & & & & & 4423 & معمل النسيج & 4 \\
\hline & & & & & 118 & الصناعي 1 & 5 \\
\hline & & & & & 2476 & الصناعي 2 & 6 \\
\hline & & & & & 1886 & التصنيع العكري & 7 \\
\hline & & & & & 650 & الجامعة & 8 \\
\hline & & & & & 4316 & النور & 9 \\
\hline & & & & & 5035 & الاسكان 1 & 10 \\
\hline & & & & & 4850 & الاسكان 2 & 11 \\
\hline & & & & & 701 & الصناعي الجديد 1 & 12 \\
\hline & & & & & 187 & الصناعي الجديد2 & 13 \\
\hline & & & & & 1003 & الصناعي الجديد3 & 14 \\
\hline & & & & & 5429 & المرتضى & 15 \\
\hline & & & & & 2026 & مجمع المخازن 1 & 16 \\
\hline & & & & & 256 & مجمع المخازن 2 & 17 \\
\hline
\end{tabular}

المصدر : مديرية احصاء بابل , تقديرات سكان مدينة الحلة , بيانات غير منشورة ,2016. ملاحظة كل الارقام التي ترد في

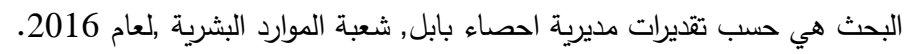
495 
يلاحظ من جدول (4) ان سكان المدينة يتوزعون على اربعة قطاعات , وكان توزيعهم بالشكل

1- قطاع الفردوس (1) : يقع في الجانب الثرقي من الددينة , ويبلغ عدد سكانه (60538) نسمة يتوزعون على

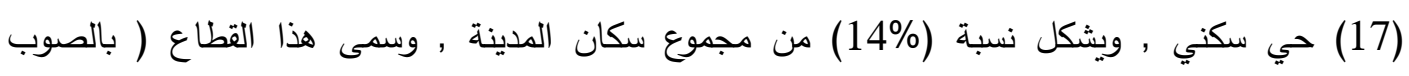

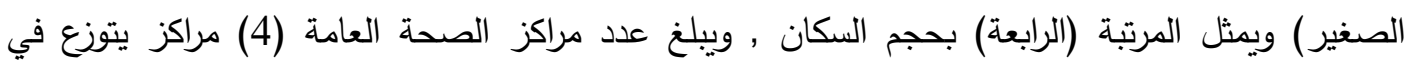

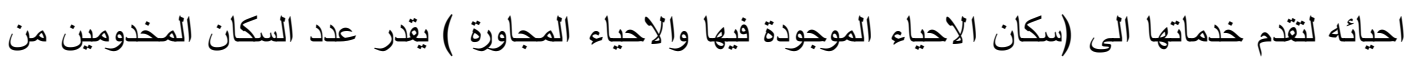

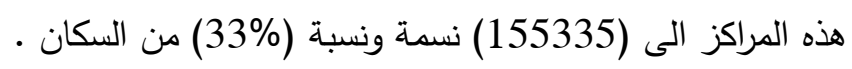

2- قطاع الفيحاء (2)

يقع في الجانب الغربي من المدينة ويمثل المنطقة القديمة ( القديمة او القلب التجاري للمدينة , ورغم تعدد الوظائف وتتوعها ضمن هذا القطاع الا ان هناك تكتل سكاني , للميزات التي يتمتع بها هذا القطاع , فيحتل المرتبة (الثالثة) بحجم السكان , ويضم (24) حي ويبلغ عدد سكانه 

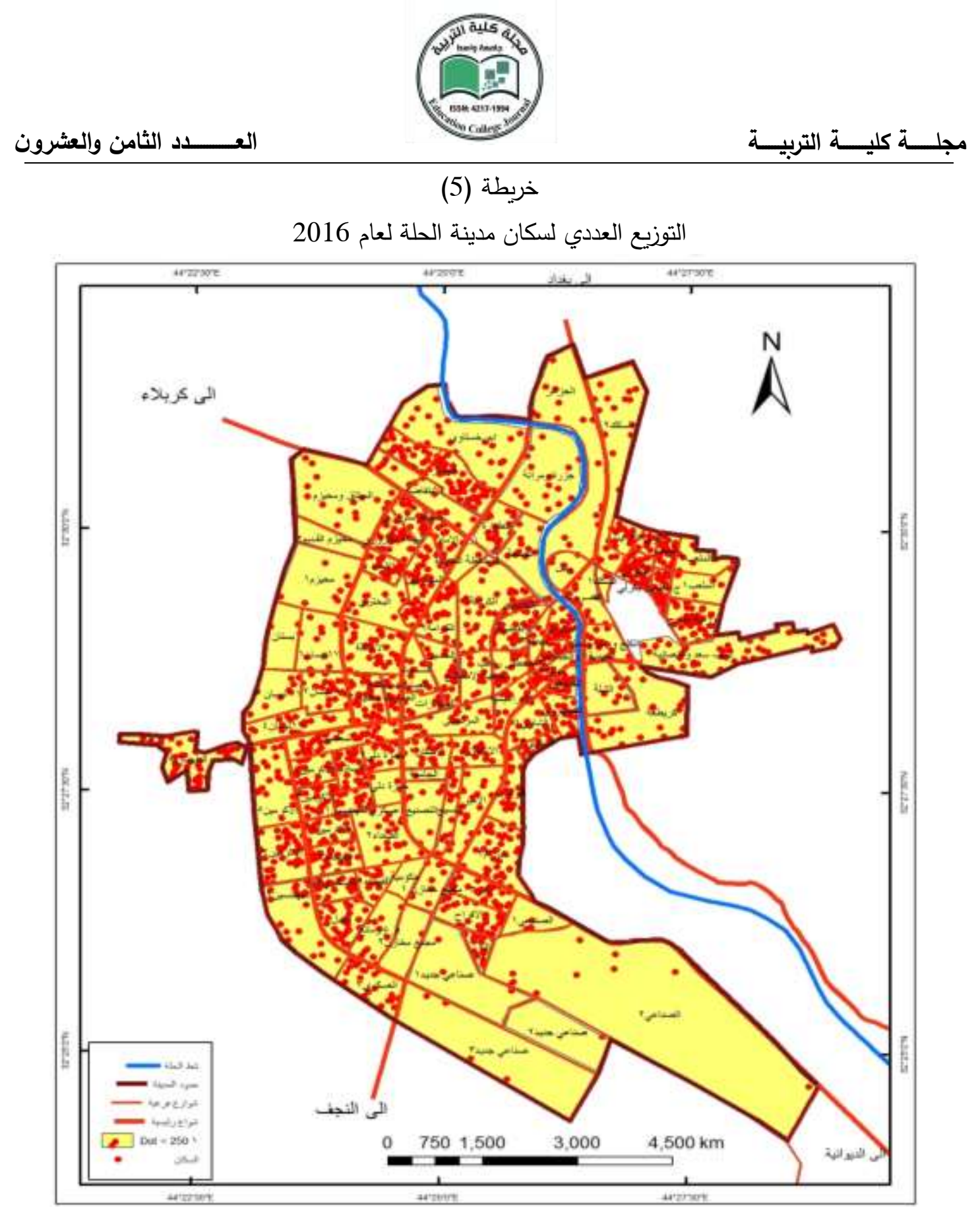

المصدر : من عمل الباحثين بالاعتماد على جدول (4) 
(73518) نسمة وبنسبة (16\%) ويبلغ عدد المراكز الصحة العامة (3) مركز صحي , يصل حجم السكان المخدومين (99276) نسمة , وبنسبة (21\%) من مجموع السكان المخدومين.

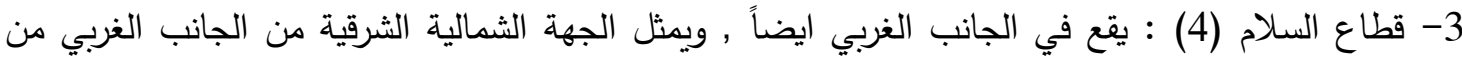

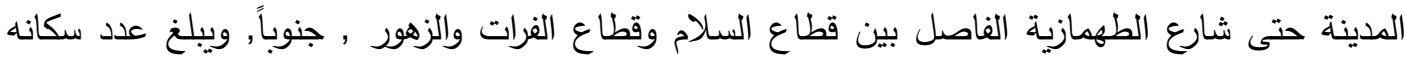
(160093) نسمة وبنسبة (36\%) من سكان الدينة , يمثل الدينة الاولى , تتوزع في القطاع (5) مراكز صحية عامة , تخدم (129730) نسمة وبنسبة (27\%) من السكان المخدومين. 4- قطاع الفرات والزهور (6) : وهو امتداد لقطاع السلام من شارع الطهمازية شمالاً بأتجاه الددينة الجنوبية

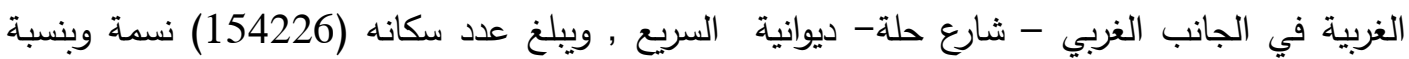
(34\%) , من سكان المدينة , وتتوزع فيه (5) مراكز صحة عامة تخدم (94674) نسمة , وبنسبة (19\%) من مجموع السكان المخدومين , ويحتل المرتبة الثانية بحجم السكان.

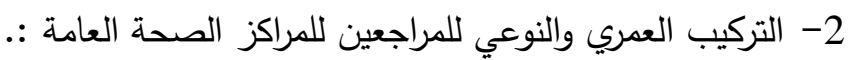

ويقصد به تقسيم السكان ( المراجعين ) الى فئات عمرية معينة , ومن الجدول ( 5) نلاحظ ان اعلى نسبة

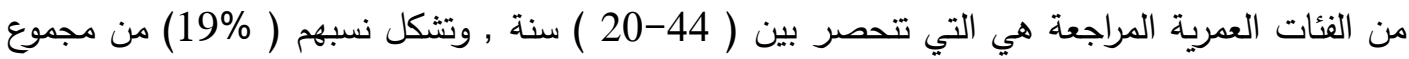

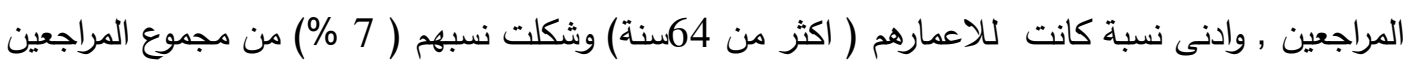
للمراكز الصحة العامة, وذلك لانهم يحتاجون الى خذمة تتجاوز الدعالجات البسيطة .

جدول ( 5) المعدل الثهري لعدد المراجعين حسب الفئات العمرية للمراكز الصحة العامة( لعام $2016 / 2015)$

\begin{tabular}{|c|c|c|c|c|c|c|c|c|}
\hline اكثرمن64 & $64-45$ & $44-20$ & 19-15 & 14-10 & $9-5$ & 4-1 & اقل من سنة & المركز \\
\hline 10518 & 6306 & 281 & 4452 & 3495 & 4975 & 2471 & 1977 & الباقر \\
\hline 1977 & 9174 & 5841 & 7344 & 6912 & 6790 & 7007 & 5677 & الخالصة \\
\hline 1618 & 3640 & 2525 & 1416 & 1538 & 6312 & 7520 & 4770 & مرجان \\
\hline 595 & 1586 & 3838 & 1733 & 982 & 1931 & 1683 & 1020 & وردية خارج \\
\hline 618 & 1382 & 4512 & 2185 & 813 & 2010 & 1882 & 1382 & المركز \\
\hline 819 & 2315 & 6892 & 8584 & 3379 & 1669 & 2434 & 3164 & القاضية \\
\hline 2778 & 3650 & 9152 & 4325 & 5956 & 6459 & 9682 & 7552 & الهادي \\
\hline 1815 & 7215 & 10513 & 4112 & 2512 & 4780 & 2391 & 1788 & الزهراء \\
\hline 512 & 1568 & 2415 & 1602 & 865 & 2618 & 1399 & 1289 & القدس \\
\hline 1940 & 1012 & 3519 & 2121 & 3891 & 4602 & 7692 & 5404 & بابل \\
\hline
\end{tabular}




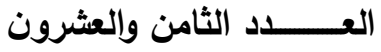

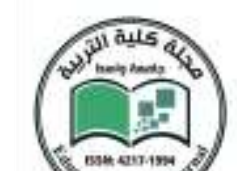

\begin{tabular}{|c|c|c|c|c|c|c|c|c|}
\hline 2880 & 989 & 3290 & 1112 & 912 & 1708 & 2922 & 2773 & الاساتذة \\
\hline 2665 & 3622 & 7812 & 1968 & 13218 & 14578 & 3817 & 1013 & الامام \\
\hline 1415 & 2677 & 6325 & 1929 & 11815 & 12513 & 3298 & 1483 & الكوثر \\
\hline 3367 & 4312 & 6528 & 2930 & 14493 & 13177 & 1680 & 860 & النهضة \\
\hline 1918 & 2125 & 4512 & 1783 & 1243 & 7395 & 8942 & 7628 & شهاء نادر \\
\hline 5819 & 7645 & 9475 & 1290 & 11889 & 2873 & 2418 & 4716 & المهندسين \\
\hline 2879 & 5698 & 4817 & 3165 & 13897 & 11517 & 849 & 1965 & شهيدالاسلام \\
\hline 44133 & 64916 & 113247 & 52046 & 93210 & 105907 & 68087 & 54461 & المجموع \\
\hline 7 & 11 & 19 & 9 & 16 & 18 & 11 & 9 & نسبة \% \\
\hline
\end{tabular}

المصدر :من عمل الباحثتين , بالاعتماد على بيانات مديرية صحة بابل, 2015, بيانات غير منشورة .

اما حسب التركيب النوعي للمراجعين, , هو تقسيم المراجعين الى مراكزالصحة العامة من ذكور واناث , وكانت نسبة توزيعه بالثكل التالي , بلغ عدد مراجعات الذكور (396344) مراجع , وبلغ عدد مراجعات

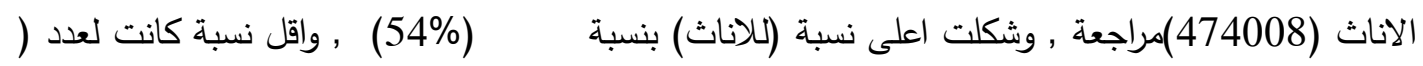

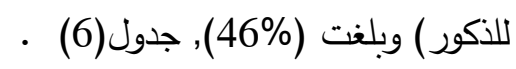


جدول (6) عدد المراجعين , حسب النوع لمراكز الصحة العامة لعام 2016

\begin{tabular}{|c|c|c|c|c|}
\hline$\%$ & عدد الاناث & $\%$ & عدد الذكور & اسم المركز \\
\hline 6 & 27262 & 4 & 16230 & الباقر \\
\hline 7 & 35558 & 8 & 31620 & الخالصية \\
\hline 6 & 31314 & 6 & 24461 & مرجان \\
\hline 2 & 9090 & 2 & 6409 & وردية خارج \\
\hline 5 & 25918 & 6 & 23514 & المركز \\
\hline 6 & 26694 & 5 & 20742 & القاضية \\
\hline 9 & 43344 & 10 & 39671 & الهادي \\
\hline 7 & 33733 & 7 & 28401 & الزهراء \\
\hline 7 & 31502 & 7 & 28915 & القدس \\
\hline 7 & 32456 & 6 & 21707 & بابل \\
\hline 6 & 27617 & 5 & 19365 & الاساتذة \\
\hline 5 & 22029 & 5 & 20531 & الامام \\
\hline 3 & 12408 & 3 & 12344 & الكوثر \\
\hline 4 & 16795 & 6 & 22136 & النهضة \\
\hline 6 & 32032 & 6 & 25246 & شهاء نادر3 \\
\hline 6 & 31618 & 7 & 26040 & المهندسين \\
\hline 7 & 34638 & 7 & 28912 & شهيد الاسلام \\
\hline 100 & 474008 & 100 & 396344 & المجموع \\
\hline 54 & & 46 & & المجموع الكلي \\
\hline
\end{tabular}

المصدر : من عمل الباحثتين بالاعتماد على بيانات صحة بابل, بيانات غير منشورة ,2015. 
المبحث الثاني : بناء قاعدة بيانات سكانية وصحية لمر اكز الصحة العامة في مدينة الحلة , وحسب الخصائص الوظيفية لكل مركز باستخدام (GIS).

يكون ذلك عن طريق معرفة مواقعها الجغرافية وخصائصها الوظيفية والتي انفردت الجغرافية بدراسة البعد المكاني عن غيرها من العلوم اذ ركزت على الظاهرة الجغرافية وتوزيعها وموقعها وانتظامها من المكاني

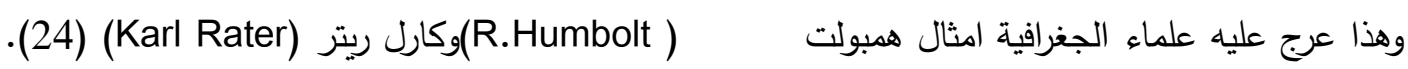

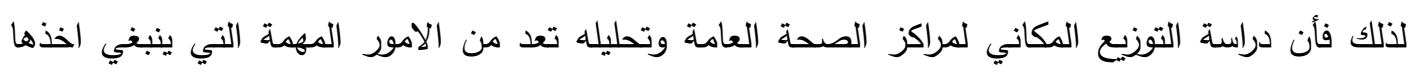

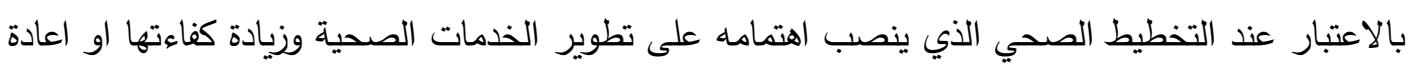

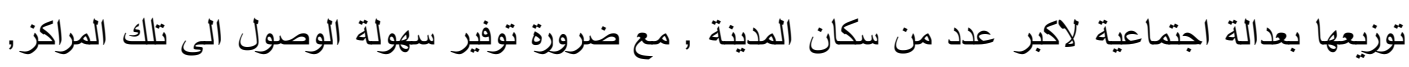
وهذا ما اكدته مؤشرات منظمة الصحة العامة عام 1977 بالسعي لتوفير الخدمات الصدية الصحية لجميع السكان

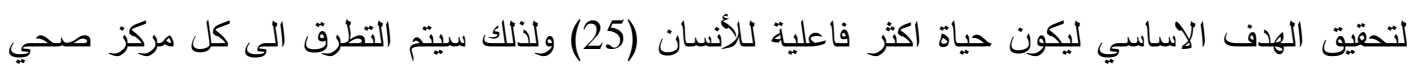

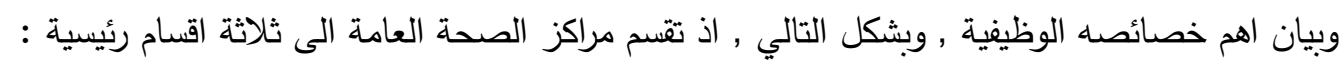

1- المراكز الصحية العامة : والتي تقدم خدمات علاجية ووقائية وتحويل الحالات الصعبة الى مراكز تخصصية

$$
\text { او الى المستثفيات , جدول(7). }
$$

2- عيادات شعبية : اذ هي صغيرة في ملاكها الوظيفي لكنها اكثر تماساً مع السكان لوجودها في وسط مراكز

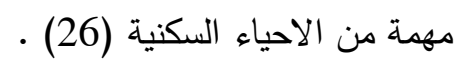

3- مراكز وقائية وتخصصية :وهي مراكز متخصصة في علاجات حالات مات معينة وتكون اكثر تخصصا وتدار من

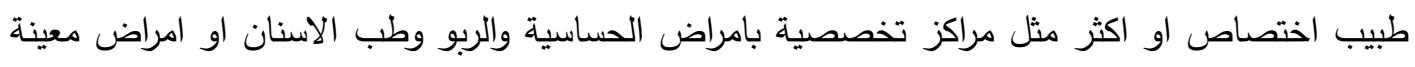

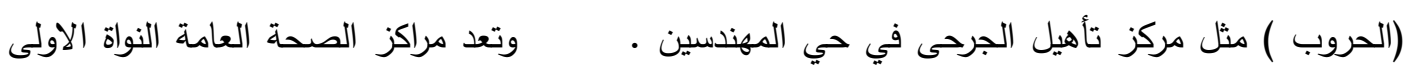

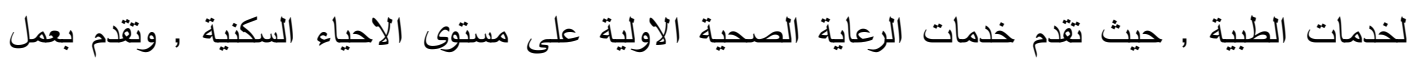

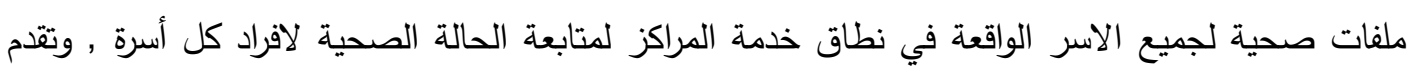

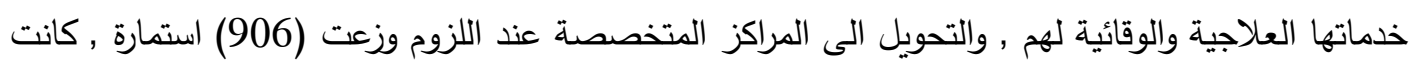

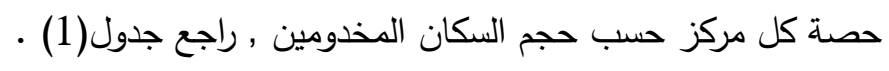


العـــــــد الثامن والعشرون

مجلــــة كليـــــة التربيــــة

جدول(7) توزيع مراكز الصحة العامة على مستوى قطاعات المدينة لعام 2016/2015.

\begin{tabular}{|c|c|c|c|c|c|}
\hline عدد المراكز & الثعبية العيادات & عدد & / عدمة السكان & اسم القطاع & ت \\
\hline I & 3 & 4 & 65038 & قطاع & 1 \\
\hline 1 & 2 & 3 & 73518 & قطاع الفيحاء & 2 \\
\hline 3 & 4 & 5 & 160093 & قطاع السلام & 3 \\
\hline 1 & 4 & 5 & 154226 & قالزهاع الفرات & 4 \\
\hline 5 & 13 & 17 & 452875 & المجموع & \\
\hline
\end{tabular}

المصدر : من عمل الباحثتين بالاعتماد على جدول(4), وبيانات مديرية صحة بابل , بيانات غير منشورة (2015 ـملاحضة

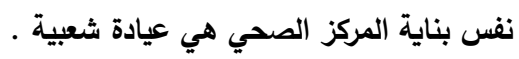


مدامد الثامن والعشرون

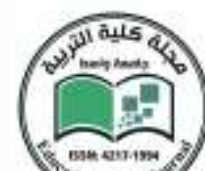

\begin{tabular}{|c|c|c|c|c|c|c|c|c|c|}
\hline \multicolumn{10}{|c|}{ لعام2015-2016 } \\
\hline كادر اداري & مهن صحية & ممرض او ممرضة & صيلي & طبيب اسنان & طبيب & المساحة م2 & المي) & اسم المركز & القطاع \\
\hline 9 & 14 & 5 & 3 & 3 & 9 & 400 & كريطعة كرة ك & الباقر & الفردوس \\
\hline 9 & 11 & 8 & 1 & 5 & 14 & 350 & البكرلي & الخالصية & 2 \\
\hline 8 & 14 & 8 & 3 & 6 & 8 & 350 & بابل ابل & مرجان & 3 \\
\hline 9 & 15 & 10 & 1 & 1 & 6 & 500 & وردية & وردية خارج & 4 \\
\hline$\underline{35}$ & $\underline{54}$ & 31 & $\underline{8}$ & $\underline{15}$ & $3 \underline{7}$ & $\underline{1600}$ & & & \\
\hline & & & & & & & & & الفيحاء ل لماء \\
\hline 7 & 4 & 5 & 2 & 4 & 3 & 300 & المركز & المركز & \\
\hline 7 & 6 & 13 & 3 & 5 & 6 & 1000 & القاضية & القاضية & \\
\hline 7 & 10 & 6 & 1 & 6 & 6 & 450 & 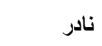 & الهادي & \\
\hline$\underline{21}$ & $\underline{20}$ & $\underline{24}$ & $\underline{6}$ & $\underline{15}$ & $\underline{15}$ & $\underline{1750}$ & & & \\
\hline & & & 3 & & 6 & 4 & |لصدر & (t) & قطاع \\
\hline $\begin{array}{l}8 \\
7\end{array}$ & $\begin{array}{c}11 \\
9\end{array}$ & $\begin{array}{l}7 \\
8\end{array}$ & $\begin{array}{l}3 \\
2\end{array}$ & $\begin{array}{l}5 \\
4\end{array}$ & $\begin{array}{l}6 \\
5\end{array}$ & $\begin{array}{l}400 \\
450\end{array}$ & الطهمازية & 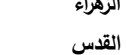 & ( اسעק \\
\hline 9 & 7 & 8 & 3 & 9 & 5 & 500 & الجمعية & بابل التلتريبي & 2 \\
\hline 8 & 10 & 9 & 3 & 4 & 4 & 500 & الاساتذة & الاساتذة & 3 \\
\hline 7 & 9 & 8 & 2 & 3 & 5 & 450 & 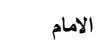 & الامام & 4 \\
\hline$\underline{39}$ & 46 & $\underline{40}$ & 13 & $\underline{25}$ & $\underline{25}$ & $\underline{2300}$ & & & \\
\hline 8 & 8 & 7 & 2 & 3 & 4 & 400 & الامير & الكوثر & \\
\hline 7 & 9 & 7 & 1 & 3 & 5 & 550 & الاسكان & النهضة & 1 \\
\hline 8 & 12 & 8 & 3 & 5 & 3 & 600 & 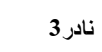 & شهاءونادر3 & 2 \\
\hline 9 & 7 & 9 & 2 & 4 & 4 & 350 & مهنسين 1 & المهندسين & 3 \\
\hline 7 & 8 & 9 & 3 & 3 & 3 & 400 & العسكري 1 & شهاء الاسلام & 4 \\
\hline$\underline{39}$ & $\underline{34}$ & $\underline{40}$ & $\underline{11}$ & $\underline{18}$ & $\underline{19}$ & $\underline{2250}$ & & & 5 \\
\hline 134 & 154 & 135 & 38 & 73 & 96 & 7900 & 17 & 17 & المجموع \\
\hline
\end{tabular}

المصدر : من عمل الباحشين بالاعتماد على جدول(4) , وبيانات مديرية صحة بابل , بيانات غير منشورة (2015 2016).

تتوزع في المدينة (17) مركزا للصحة العامة , خريطة( 6) وهي في اغلبها عيادات شعبية تقدم خدماتها لسكان احياء المدينة عدا (4) مراكز تخصصيا , بل عدد الاطباء الاختصاص في المراكز (96) طبيبا , و(73) طبيب اسنان , و(38) صيدلي , و(154) من 


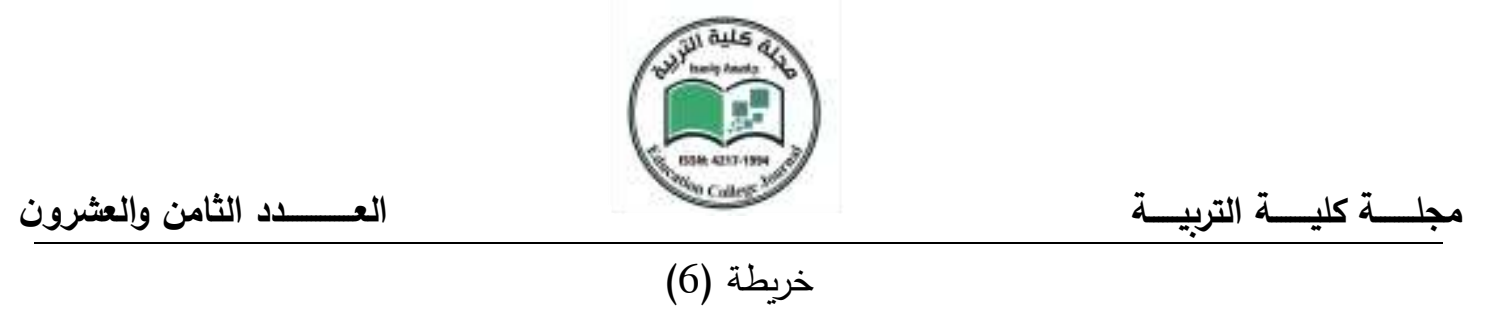

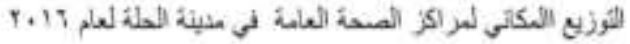

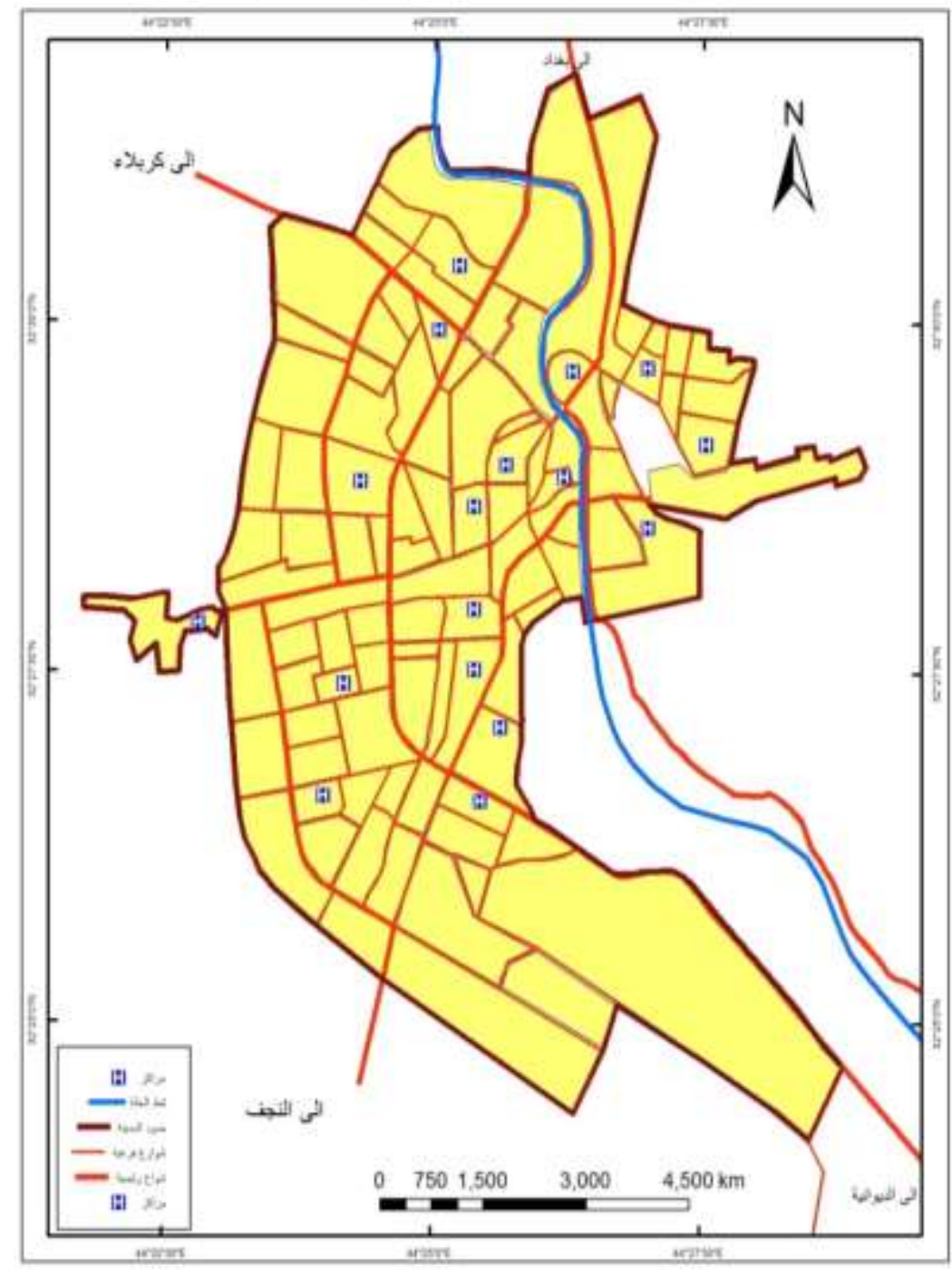

المصدر : من عمل الباحثتين بالاعتماد على جدول(8) , لعام 2016. 
اصحاب المهن الطبية و(204) يعملون في الكادر الاداري , اما اهم الخصائص الاحصائية الوصفية لكل

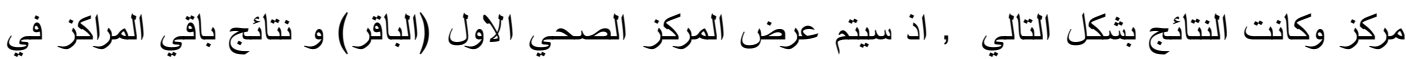

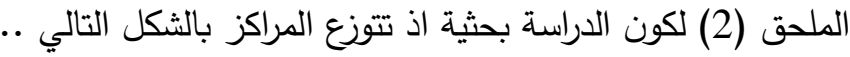
(أ) قطاع الفردوس : وتتوزع فيه (4) مراكز صحة عامة في احياء القطاع .

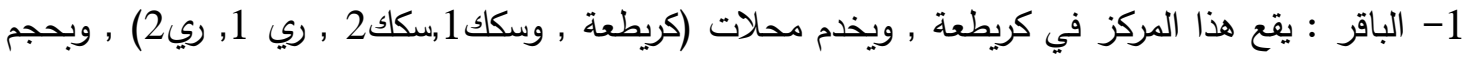

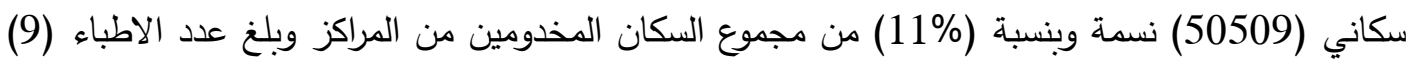

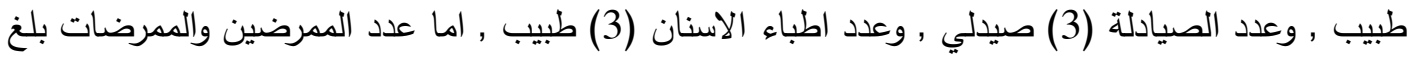

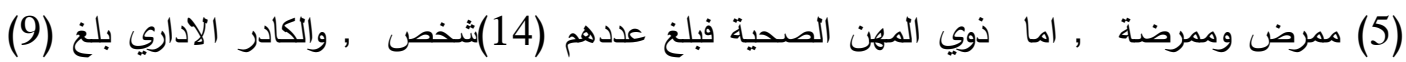

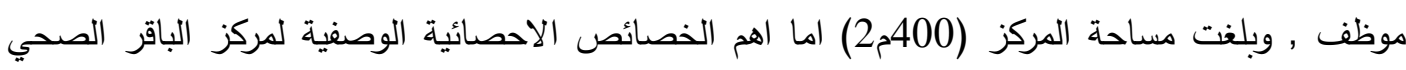

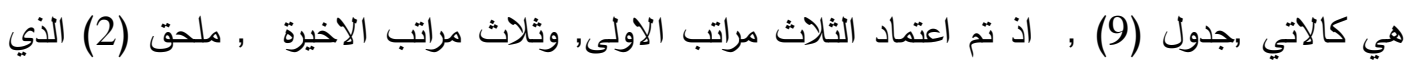
يوضح الخصائص الإحصائية والوصفية لمراكز الصحة العامة جميعها باستخدام (spss) . جدول (9) الخصائص الاحصائية الوصفية لعينة الاراسة لمراكز الخدمات الصحية في مركز (الباقر ) الصحي في كريطعة .

\begin{tabular}{|c|c|c|c|c|}
\hline الالنبية & نالفبة & الحسابي & 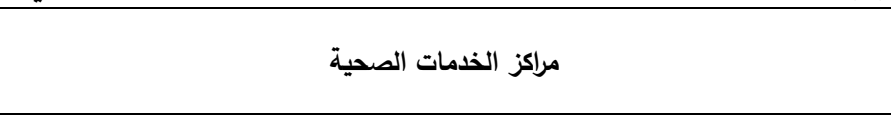 & 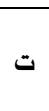 \\
\hline 13 & 11,54 & 2,37 & تتوفر مراكز صحية متعددة الاختصاصات & 1 \\
\hline 10 & 19,23 & 2,42 & المراكز الصحية تتوفر فيها جميع الادوية & 2 \\
\hline 3 & 28,85 & 2,87 & المراكز الصحية فيها اطباء اختصاصيين & 3 \\
\hline 11 & 19,23 & 2,29 & المراكز الصحية تستقبل المرضى في ايام العطل & 4 \\
\hline 5 & 25,00 & 2,46 & المراكز الصحية فيها خفارات ليلية & 5 \\
\hline 7 & 21,15 & 2,37 & يمكن الوصول الى المركز الصحي من خلال النقل العام & 6 \\
\hline 12 & 15,38 & 2,35 & يتوفر في المركز الصحي خدمة الاسعاف الفوري & 7 \\
\hline 1 & 56,38 & 3,65 & المركز الصحي يعمل بطاقات صحية للاسرة والافراد & 8 \\
\hline 2 & 55,77 & 3,29 & المركز الصحي يقدم خدمة رعاية الحوامل والاطفال & 9 \\
\hline 8 & 21.15 & 2,65 & المركز الصحي يوفر خدمة الرعاية الصحية لذوي الاحتياجات الخاصة & 10 \\
\hline 4 & 26,92 & 2,75 & المركز الصحي يوفر خدمة العالجة الموقعية ( في المنزل ) للعاجزين وكبار السن & 11 \\
\hline 6 & 21,15 & 2,60 & يتولى المركز نقل الحالات العاجز عن علاجها الى المركز الرئيس ومتابعة حالة المريض & 12 \\
\hline \multirow[t]{2}{*}{9} & 19,23 & 2,58 & توجد في المركز الصحي صالة طواري وصالة عليات صغرى & 13 \\
\hline & 26,92 & 2,66 & المتوسط العام للمحور & \\
\hline
\end{tabular}

المصدر : استمارة الاستبانة , الموزعة على المراجيين للمراكز الصحية , لعام 2016/2015. 505 
يظهر جدول (9) المتوسط الحسابي ونسبة الاتفاق والاهمية النسبية لمستويات الاجابة حول محور مراكز الخدمات الصحية ونستخلص منه المؤشرات التالية:

1- بلغ المتوسط العام للمحور ما قيمته (2,66) وهو ادنى من الوسط الفرضي البالغ (3) ـ وبمعل نسبة اتفاق قرهها

(26.92) مؤشرا ضعف الخدمات الصحية بنظر المبحوثين.

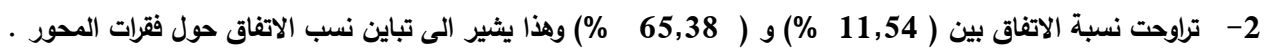

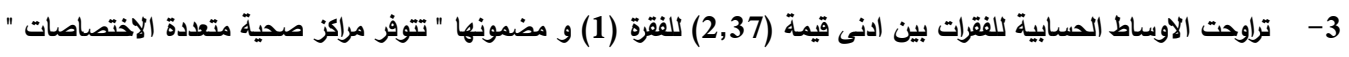

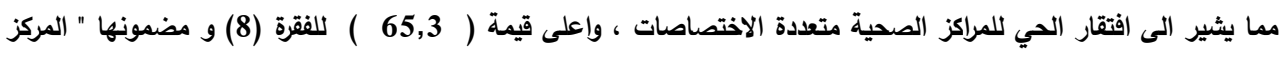

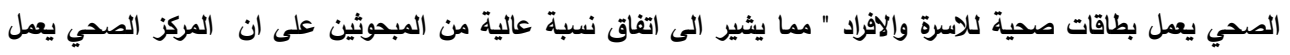

ببطاقات صحية للاسرة والافراد.

4- ان اغلب الاجابات على فقرات المحور تتفق على تدني الذذمات الصحية في هذا الحي.

2- الخالصية :. يقع هذا المركز في حي البكرلي , ويخدم سكان كل من (البكرلي ملعب1, ملعب2, الخضر) وبحجم سكاني (40778) نسمة وبنسبة (9\%) من السكان المخدومين تتوافر في المركز كوادر طبية , عدد الاطباء (14) طبيب , و (5) اطباء الاسنان , ( 1) صيدلي , وعدد الممرضين والممرض (8) اما ذوي المهن الطبية فبلغ عددهم (11) والكادر الادراي بلغ عددهم (9) اشخاص , اما مساحة المركز فبلغت .$(2,350)$

3- مرجان : يقع هذا المركز في حي بابل وهو مركز صحي وليس عيادة شعبية ويخدم محلات (بابل , الجزائر , الخسروية , الكلج ) وبحجم سكاني (26611) نسمة , وبنسبة (6\%) من السكان المخدومين .وتتوافر في المركز كوادر صحية , فبلغ عدد الاطباء (8) طبيب , وصيادلة (3) صيدلي , وطبيب اسنان عدد (6) , اما ذوي المهن الصحية فبلغ عددهم (14) , والكادر الاداري بلغ عددهم (8) موظف وموظفة وبلغت مساحة المركز (250) (20)

4- وردية خارج : يقع في حي الوردية ويخدم سكان احياء الوردية داخل والوردية خارج , سيف سعد والنعمانية , بحجم سكاني بلغ (37437) نسمة وبنسبة (8\%) من مجموع السكان المخدومين , وبلغت مساحته (500م2) م2 بلغ عدد الاطباء (6) طبيب , وطبيب اسنان عدد (1) , وصيدلي (1) و (10) ممرض وممرضة , في حين بلغ عدد ذوي المهن الصحية (15) شخص في المركز صحي وعدد الكادر الاداري (9) 
1- المركز : يقع في مركز المدينة ( المدينة القديمة ) , ويخدم سكان احياء المهدية 1 , المهدية (2) , الجباوين والاكراد , بحجم سكاني (5955) نسمة وبنسبة (1\%) من سكان المخدومين , وتتوافر في المركز كادر المريك

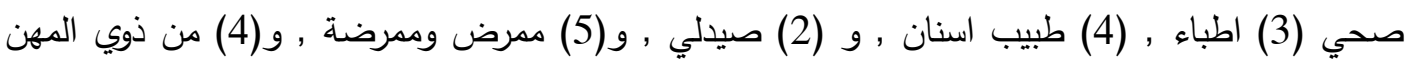

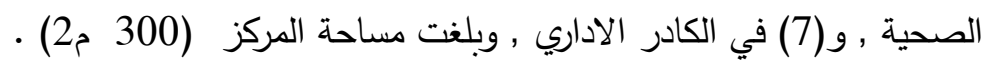
2- القاضية : يقع في حي القاضية , ويخدم حجم سكاني يبلغ (41094) نسمة وبنسبة (9\%) من من مجموع الدارية السكان المخدومين , ويخدم احياء (القاضية مصطفى راغب , المهدية 3 , شبر وجديدة )ويتوافر في المركز

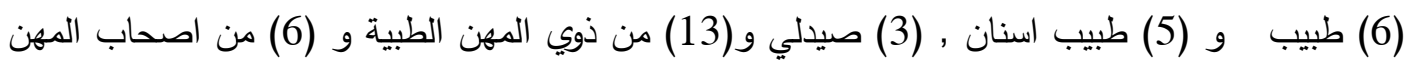
الصحية , و (7) في الكادر الاداري, وبلغت مساحة المركز (1000م2) .

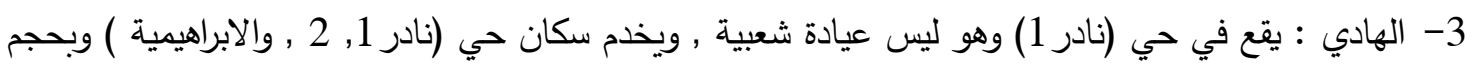

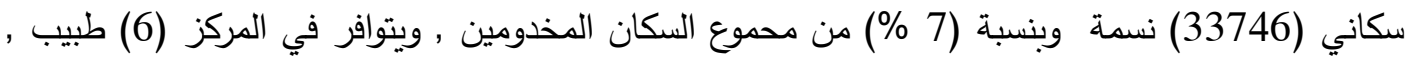

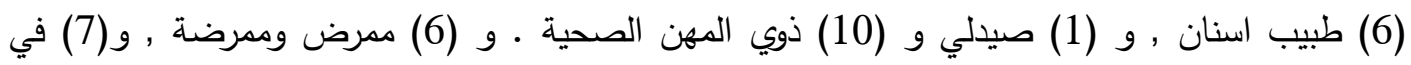

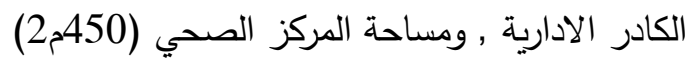

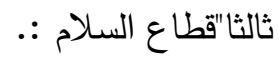

1- الزهراء / يقع في حي الصدر , ويخدم حجم سكاني (50685) نسمة وبنسبة (11\%) من محموع السكان المخدومين , ويخدم سكان الاحياء (الصدر 1, محيزم 1 , محيزم2, الانتفاضة ,ضباط مكروري, شهداء مكروري , وابو خستاوي ) ويتضمن الكادر الصحي من (6) اطباء و (5)|طباء اسنان , و و(3) صيادلة و (7) ممرضين و (11) من اصحاب المهن الصحية و (8) في الكادر الاداري , وبلغت مساحة المركز .$(2,400)$

2- القدس : يقع في حي الطهمازية /14 , ويخدم سكان احياء الطهمازية وبستان و 17 نيسان 1 , و17نيسان2, و17نيسان3) وبحجم سكاني (9798) نسمة وبنسبة (2\%) من مجموع السكان المخدومين , اما الكادر

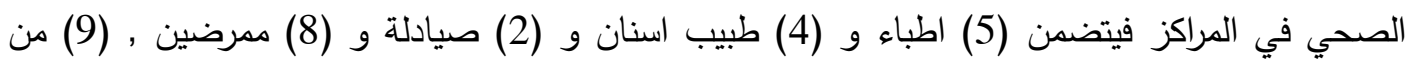
ذوي المهن الصحية و (7) في الكادر الاداري للمركز , وبمساحة (450م2) . 3- بابل التدريبي : يقع في حي ( الجمعية ) ويخدم (45833) احياء( الجمعية , كرامة2 , الاصلاح , كرامة 1) وبنسبة (10\%) من محموع السكان المخدومين , اما الكادر الصحي فيتكون من (5) اطباء و (9) اطباء 
اسنان و (3) صيادلة و (9) ممرضين و (10) مهن صحية وفي الكادر الاداري (7) موظف , وبمساحة

$(2,500)$

4- الاساتذة : يقع في حي الاساتذة , ويخدم سكان حي( الاساتذة و17البستان , و17نيسان4) وبحجم سكاني

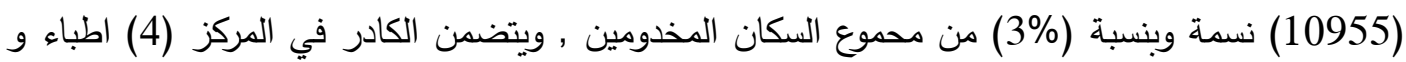

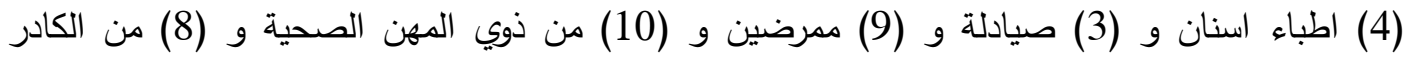

$$
\text { الاداري , وبمساحة (500م2). }
$$

5- الامام : يقع في حي الامام , ويخدم سكان حي ( الامام , الححاربين ) بحجم (5000) نسمة وبنسبة

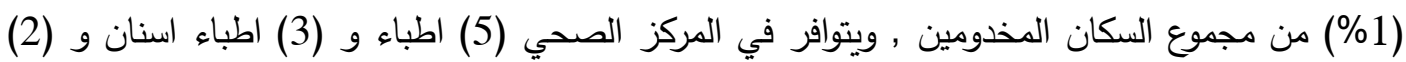

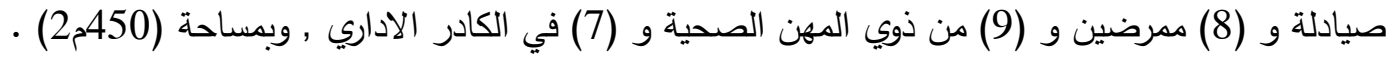

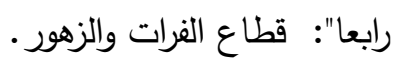
1- الكوثر / يقع في حي الامير ويخدم سكان (12231) نسمة ويخدم سكان احياء ( الافراح , صناعي1, , ونادر 3) وبنسبة (4) من مجموع السكان المخدومين , ويتوافر في المركز (4) اطباء و (3) طبيب اسنان و (2) صيدلي و (7) ممرض و (8) من ذوي المهن الصحية و (8) في الكادر الاداري , وبمساحة بلغت .$(2,400)$ 2- النهضة :يقع في حي الاسكان ويخدم سكان الاحياء (الاسكان1 , الاسكان2, النور , الجامعة ) ويخدم حجم

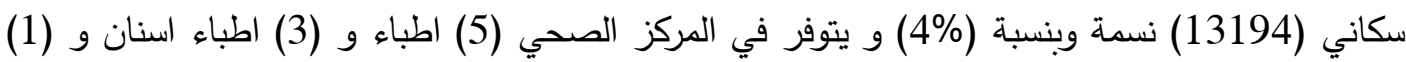
صيادلة و (7) ممرضين و (9) من اصحاب المهن الصحية و (7) في الكادر الاداري , وبمساحة بلغت . $(2,500)$ 3- شهاء نادر 3: يقع في حي نادر 3 , ويخدم سكان حي ( الامير , معمل النسيج ,نادر 1, ونادر 2) بحجم سكاني (47140) نسمة وبنسبة (10\%) من محموع السكان المخدومين , ويتوفر في المركز (3) طبيب

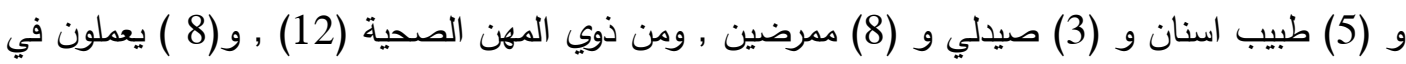
الكادر الاداري , وبمساحة بلغت (600م2). 4- المهندسين : يقع في حي المهندين , ويخدم سكان الاحياء( المهندسين1, والمهندسين2 , والمهندسين3) ويخدم المركز حجم سكاني (10955) نسمة وبنسبة (2\%) ويتوافر في المركز (4) اطباء , و (4) اطباء 
, (7) من ذوي المهن الصحية و (9) من الكادر الاداري ولادئرون

(7) (9) ممرضين و (9) (7) (1) (2)

مجلــــة كليـــة التربيــــة

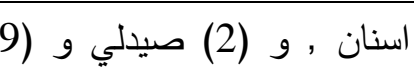

وبمساحة (350م2).

5- شهيد الاسلام : يقع في الحي العكري , ويخدم سكان الاحياء (العسكري 1, والعسكري2 , والعسكري3,

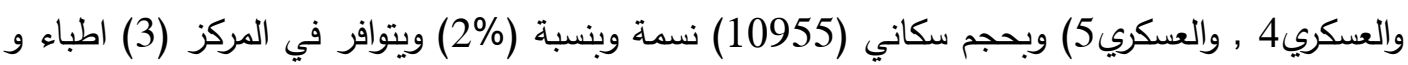

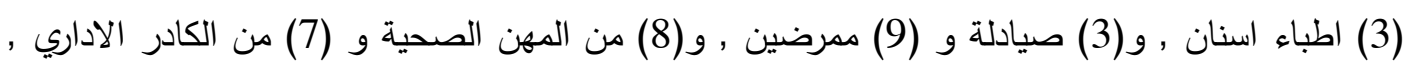

$$
\text { وبمساحة بلغت (400م2). }
$$

ب- - المراكز الصحية الوقائية او التخصية :. وتقدم خدماتها على مستوى الاحياء والقطاع , وعادة

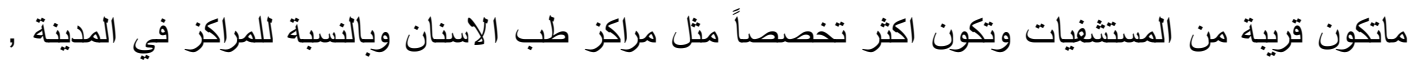
توجد (4) مراكز تخصصية . 1- مركز بابل لتأهيل الجرحى :. ويقع في قطاع الفرات في حي المهندسين على شارع(60) , ويقدم خدماته

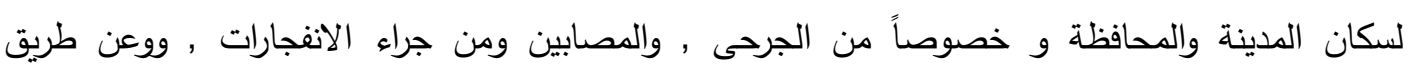

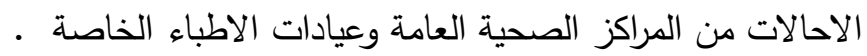
2- مركز الاسنان التخصصي :. ويقع في قطاع السلام في حي الجمعية , ويقدم خدماته لسكان الدينة

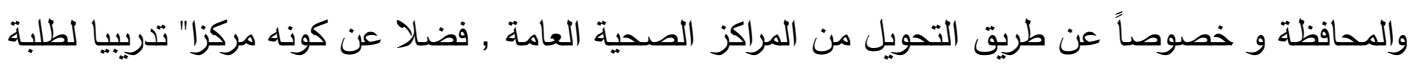
كلية طب الاسنان في بابل . 3- مركز الحساسية والربو : : ويقع في قطاع الفيحاء في حي القاضية ويقدم خدماتهه لسكان الددينة والمحافظة و خصوصاً في فترات هبوب العواصف الترابية روف وعن طريق الاحالات من مراكز الصحة العامة

4- مركز العمليات التخصصي : : ويقع في قطاع السلام في حي الاسكان , ويقدم خدماته لسكان المدينة

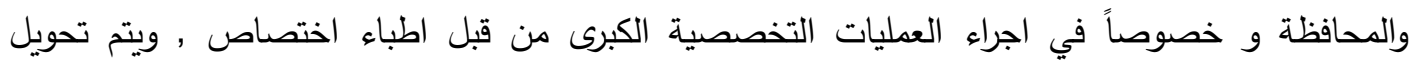
الحالات من المستشفيات القريبة . 5- مركز الامراض الصدرية والتتفسية : :. ويقع في قطاع السلام في حي الاساتذة, ويقدم خدماته لسكان المدينة و خصوصاً عن طريق التحويل من المراكز الصحية العامة . 
المبحث الثالث : كفاءة خدمات المراكز الصحية العامة لمدينة الحلة :

لقياس كفاءة خدمات مراكز الصحة العامة , استخدمت الباحثتين المعايير المعتمدة في قياس كفاءة

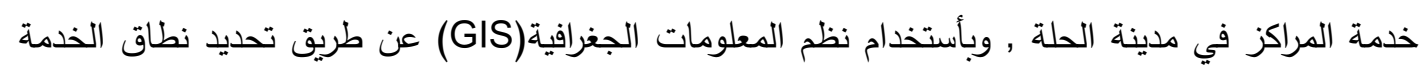

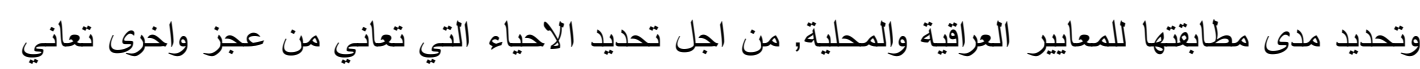

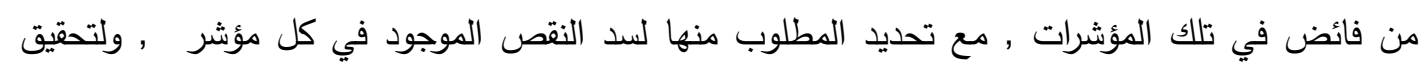

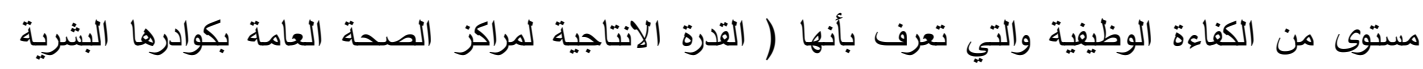

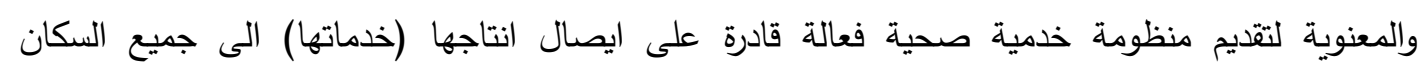
المستفيدين باقل مسافة وصول وبأقل كلفة اقتصادية ) .

لذا سيتم التطرق الى كفاءة خدمات مراكز الصحة العامة في الددينة بالاعتماد على معايير (عددية )

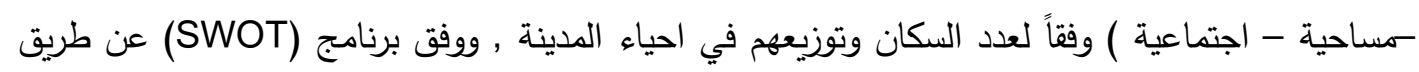
تحديد نقاط القوة والضعف في هذه الخدمة .

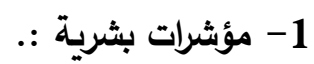

تعد المقومات البشرية الجانب الحيوي كونها تتفاعل بشكل مباشر مع السكان في المدينة من خلال ماتقدم من خدمة متمثلة بعدد العاملين من( الطبيب - الصيدلي - الممرض - طبيب الاسنان - الكادر الطبي الكادر الاداري ), وجدول (10) , وجدول(11) يوضح اهم المؤشرات والمعايير لمستخدمة لقياس كفاءة

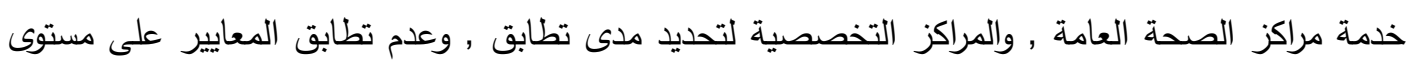

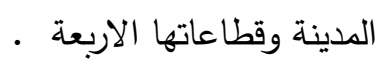


العــــــد الثامن والعشرون

مجلــــة كليـــة التربيـــة

جدول (10)المؤشرات البشرية(المؤشر / نسمة) الواجب توافرها في مراكز الصحة العامة

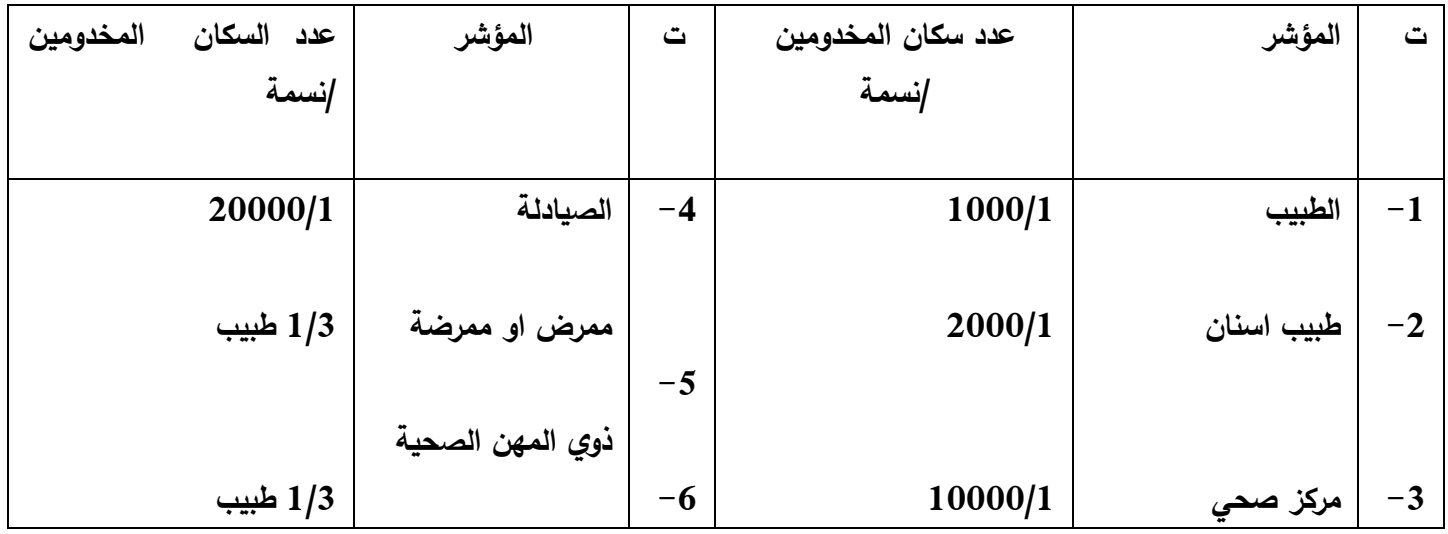

الدصدر (1) وزارة الاسكان والتعمير , معايير الاسكان الحضري , بيانات غير منشورة 2010 (2) وزارة الصحة العراقية , معايير صحية , 2011.

جدول (11) المؤشرات البشرية(المؤشر / نسمة) الواجب توافرها في المراكز التخصصية

\begin{tabular}{|c|c|c|c|}
\hline الملاحظات & الى & من & المؤشر \\
\hline على مستوى احياء & 50000/نسمة & 40000/ نسمة & عدد السكان المخدومين \\
\hline سكنية اوقطاع & & & \\
\hline & I & l & نطاق الخدمة بالمتر \\
\hline 500 بناء فقط & 4000 & 2000 & المساحة الكلية م2 \\
\hline
\end{tabular}

الصصدر (1) وزارة الاسكان والتعمير , معايير الاسكان الحضري , بيانات غير منشورة 2010 (2) وزارة الصحة العراقية ,

معايير صحية , 2011.

ومن أجل الكثف عن كفاءة مراكز الصحة العامة في المدينة وقطاعاتها , اذ تتباين في مؤشراتها العددية , وعند تطبيق المؤشرات , يوضح جدول(12) ,جدول(13) , خارطة (7) , لذا سنتطرق الى كل المؤشرات

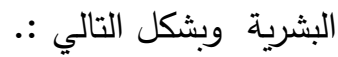

1- عدد الاطباء / السكان :. تختلف نسب عدد الاطباء الى نسبة السكان حسب طبيعة المدينة

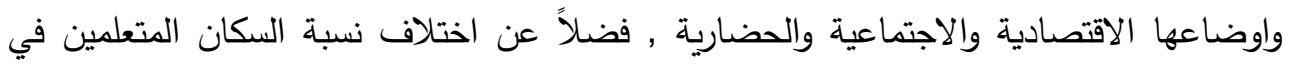


دولة فحاجة الطبيب في المجتمعات المتقدمة تختلف عن حاجة الطبيب في المجتمعات المتخلفة ,

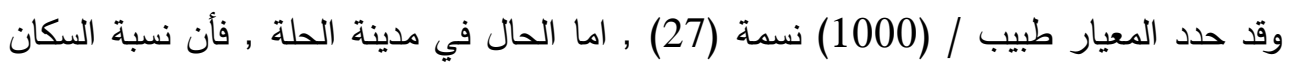
الى عدد الاطباء بلغ (4717) نسمة / طبيب وهذه النسبة تفوق المعيار المحدد مما يشكل ضغطاً

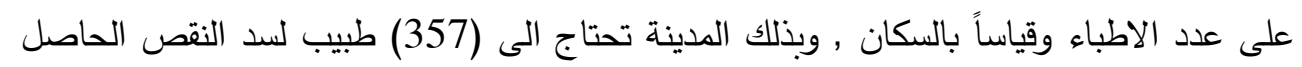

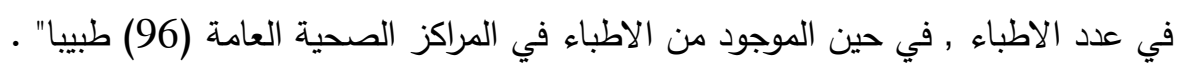

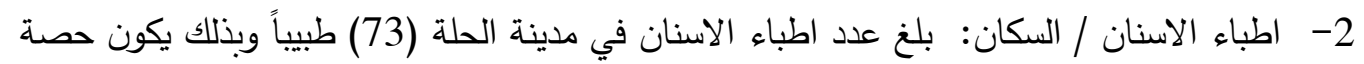

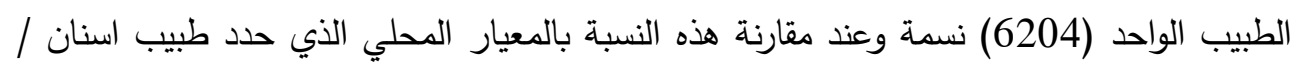
(2000) نسمة , وبذلك سجلت هذه الخدمة انخفاضاً كبيراً عن المعيار الكلي مما يجعل امكانية الكاري

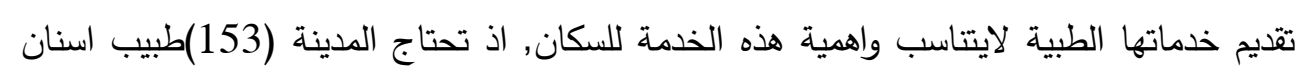
لسد النقص الحاصل . 3- عدد الصيادلة / السكان : تعد عملية توفير العلاجات اللازمة وعملية الحصول عليها من قبل

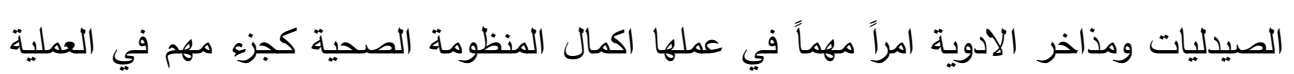

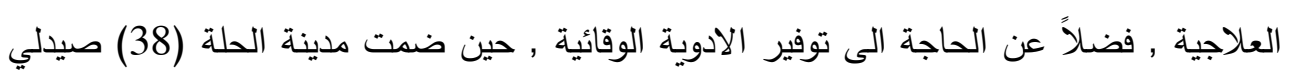

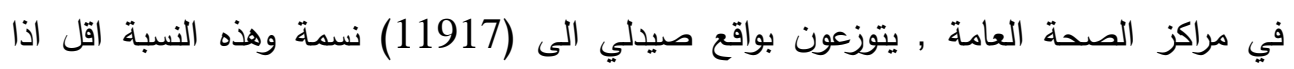

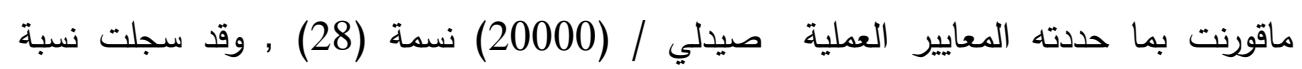
الصيادلة كفاءة عددية قياسية في المدينة الامر الذي ينعكس ايجاباً على مدى سهولة الحصول على العلاج اللازم للسكان المرضى بدون جهد او كلفة . جدول(12) الحاجة من مراكز الصحة العامة في مدينة الحلة وحسب قطاعاتها لعام (2016)

\begin{tabular}{|c|c|c|c|c|}
\hline الحاجة & عدد المراكز & المطلوب من المراكز & عدد السكان & اسم القطاع \\
\hline 3 & 4 & 7 & 65038 & الفردوس \\
\hline 4 & 3 & 7 & 73518 & الفيحاء \\
\hline 11 & 5 & 16 & 160093 & 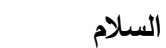 \\
\hline 10 & 5 & 15 & 154226 & الفرات والزههور \\
\hline 28 & 17 & 45 & 452875 & المجموع المجوع \\
\hline
\end{tabular}

المصدر : من عمل الباحشين بالاعتماد على جدول(4) , وجدول(8), وتطبيق المعيار امركز/100001نسمة . 


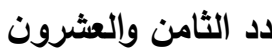

مجلـــة كليــــة التربيـــة

جدول(13) تطبيق المؤشرات البشرية لسكان قطاعات مدينة الحلة لعام (2015/ 2016)

\begin{tabular}{|c|c|c|c|c|c|c|}
\hline صحية/ طيبي & 3مرض/1طبيب & 1 اصيلني & 1طيب اسنان / & 1000نسمة/1طبيب & عدد السكان & القطاع \\
\hline 1 & 1 & 8130 & 4336 & 1758 & 65038 & الفردوس \\
\hline 1 & 2 & 12253 & 4901 & 4901 & 73518 & الفيحاء \\
\hline 2 & 2 & 12314 & 6404 & 6404 & 160093 & السلام \\
\hline 2 & 2 & 14020 & 8568 & 8117 & 154226 & والزرهور \\
\hline
\end{tabular}

الصصدر (1) وزارة الاسكان والتعمير , معايير الاسكان الحضري , بيانات غير منشورة 2010 (2) وزارة الصحة العراقية ,

$$
\text { معايير صحية , } 2011 .
$$

4- عدد المرضين / طبيب : بلغ عدد العاملين من المهن الطبية في المدينة (135) ممرضا" وهم يشكلون

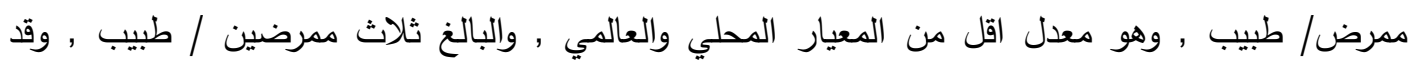

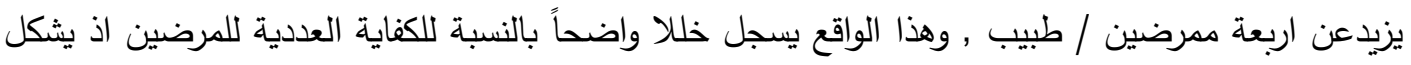

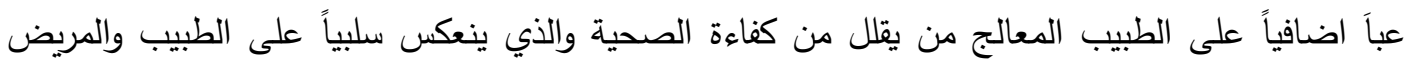

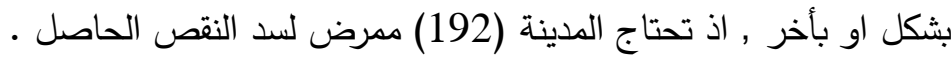

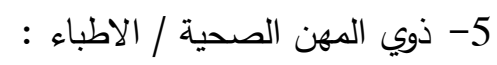

ويعد هذا من المعايير المهمة والتي تفيد في تقويم اداء الخدمات الصحية وهو معرفة نسبة ذوي المهن الصحية لكل طبيب , وقد حدد المعيار ثلاثة من العاملين من المهن الصحية / طبيب (29) , وعند تطبيق

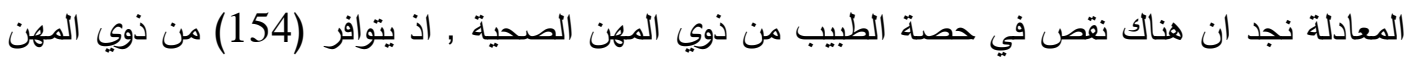

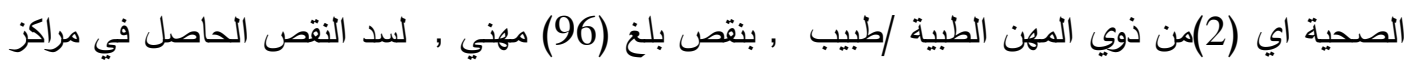
الصحة العامة , اذ يؤثر ذلك على تحقق كفاءة الاداء الذي يتلائم مع حاجة المريض والطبيب في المدينة. 6- حجم السكان / عدد الم راكز الصحية العامة:

يعد من المعايير المهمة والتي يتطلب توافرها في المدينة , اذ ان حجم السكان يعد من المؤشرات المؤشرة

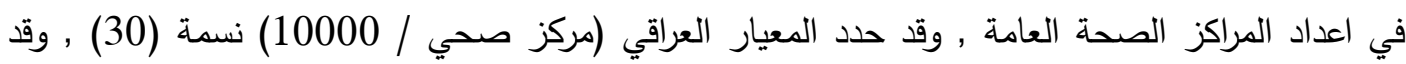

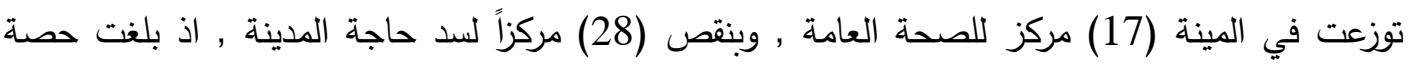


المركز (26640) نسمة مما يتطلب معالجة هذا النقص الذي يثكل ضغطاً على كفاءة المركز الصحي

ب-المعيار المساحي للمراكز الصحية : يعتبر مؤشر المساحة من المؤشرات التي تعكس رفاهية وامكانية

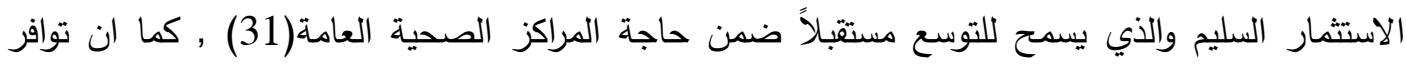

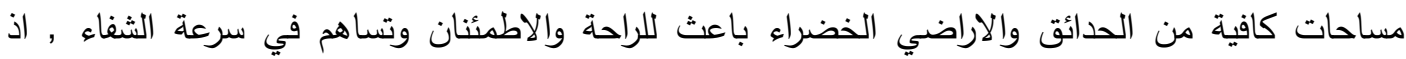

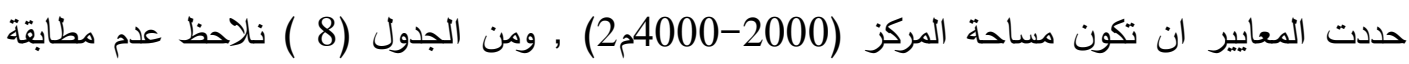
مساحة المراكز الى هذه المساحة المحددة , يضاف اليها النقص في عدد المراكز البالغة (28) مركز بمساحة

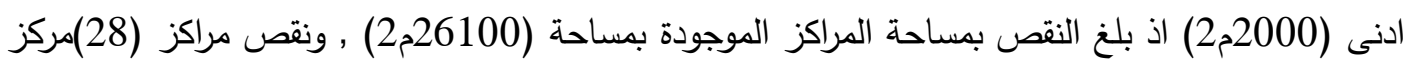

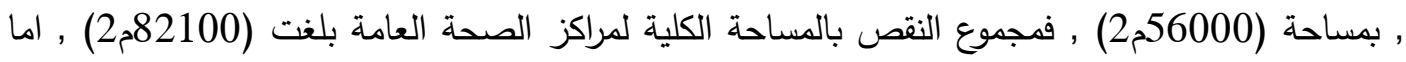

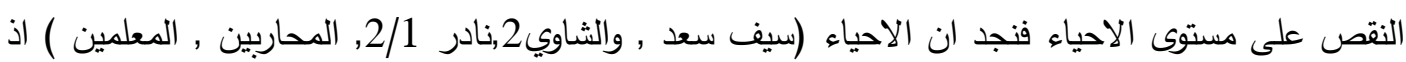

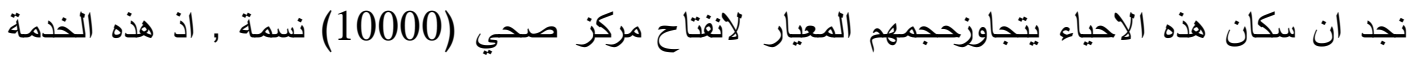

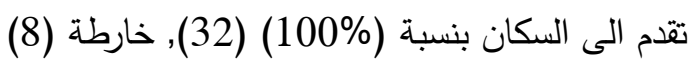

2- التوقيع المكاني : ان توافر متطلبات التوقيع المكاني لمراكز الصحة العامة في مكان وسط في الحي السكاني او المحلة السكنية او بين المحلات السكنية من الاهمية الكبيرة , كما يجب ان يكون بعيد عن المدارس والاسواق التجارية والضجيج والتلوث الضوضائي والدخان والاخطار البيئية الاخرى , في موقع يتميز بالهدوء الاهيه

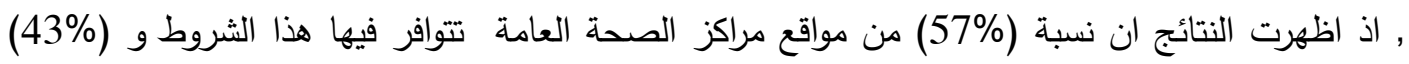

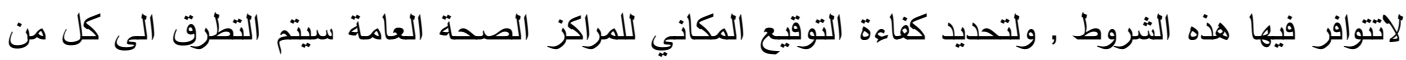

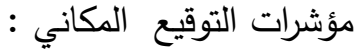



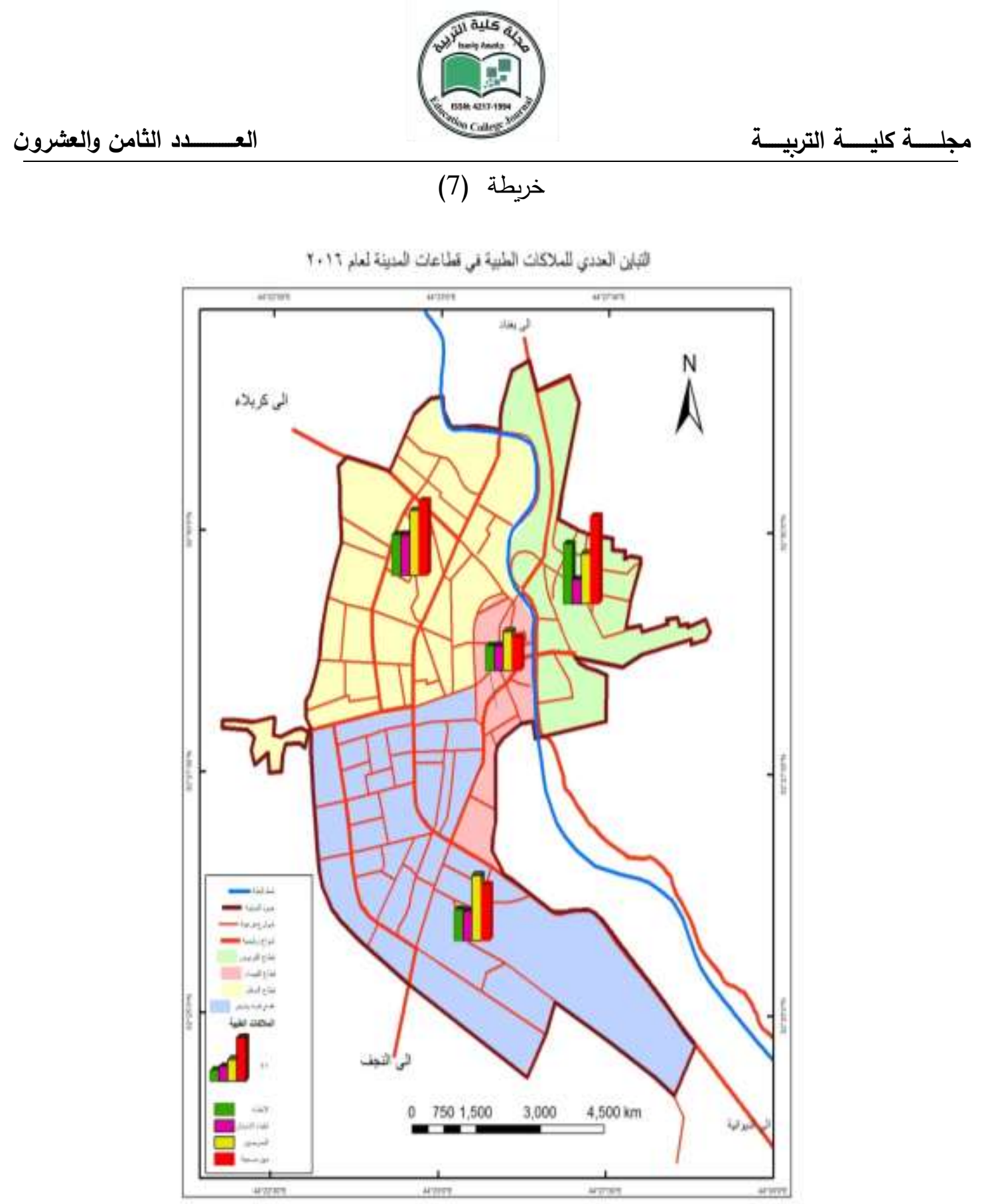

المصدر : من عمل الباحثتين بالاعتماد على جدول(8) , لعام 2016. 

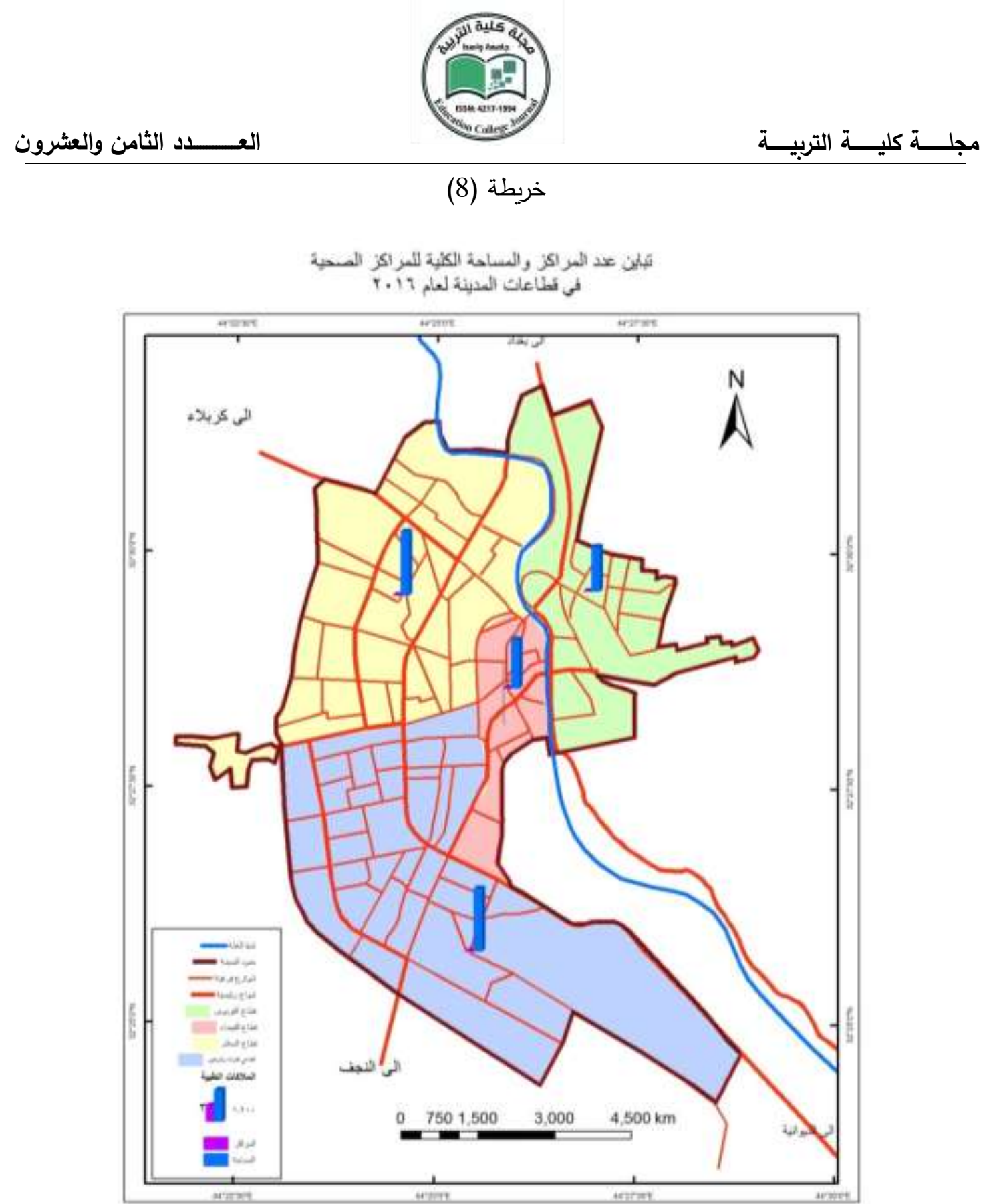

المصدر : من عمل الباحثتين بالاعتماد على جدول(8) , لعام 2016. 
1- سهولة الوصول (Accessibilty) : تعد عملية ايصال خدمات الصحة العامة لسكان الاحياء

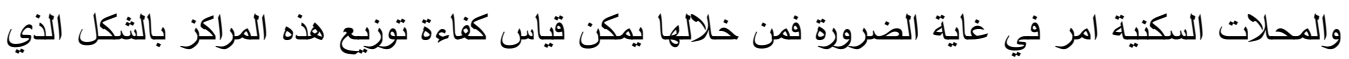
يتناسب مع حجم السكان وحاجاتهم واماكن تجمعهم فكلما كانت مواقعها مناسب من الاحياء السك نية فئس

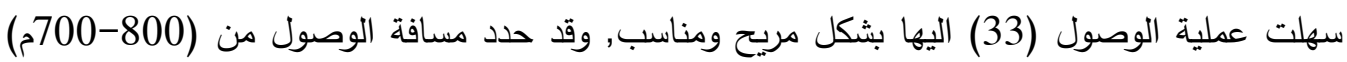

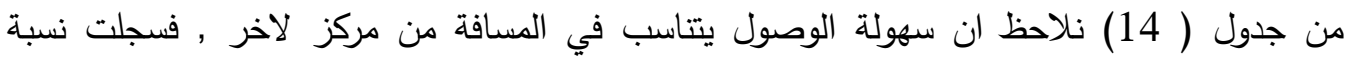
الوصول اعلى نسبة في المراكز الصحية العامة. جدول(14) النسب المئوية لنطاق الخدمة الفعلي لمراكز الصحة العامة

\begin{tabular}{|c|c|c|}
\hline \multicolumn{2}{|c|}{ لعام (2016/2015) } & \\
\hline نسب التركز \% & عددالاستمارات & المؤشر/ المسافة م \\
\hline 44 & 400 & اقل من 700 \\
\hline 31 & 275 & $800-700$ \\
\hline 25 & 231 & اكثر من 800 \\
\hline 100 & 906 & المجموع \\
\hline نسب التركز \% & عدد الاستمارات & المؤشر /وسيلة النقل \\
\hline 44 & 395 & مشي \\
\hline 22 & 200 & باص عام \\
\hline 15 & 136 & سيارة خاصة \\
\hline 19 & 175 & سيارة اجرة \\
\hline 100 & 906 & المجموع \\
\hline
\end{tabular}

المصدر : من عمل الباحثتين بالاعتماد على استمارة الاستبانة, 2015.

يلاحظ من جدول ( 14) , خارطة (9) , تباينت مسافة الوصول , الاقل من 700 , بلغت (44\%) اما بالنسبة المسافة بلغت (31\%) للمسافة الواقعة بين (800-700م) , واقلها للمسافة لاكثر من 800م , تناسبت وسائل النقل وطريقة الوصول الى المركز لصحي , اذ وسيلة الوصول (المشي) , بلغت اعلى بنسبة (44\%) , وادنى نسبة بلغت للسيارة الخاصة , اذ بلغت نسبة (15\%)

كما يفضل ان يقع المركز على طرق تجمية ورئيسة يفضل ان يتميز بموقع مراكز الصحة العامة بخاصية

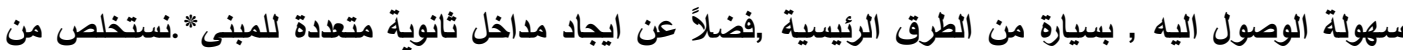


ذلك هناك نسبة عالية من المراجعيين يتوجب عليهم قطع مسافة طويلة من اجل الحصول على الذدمة , مما

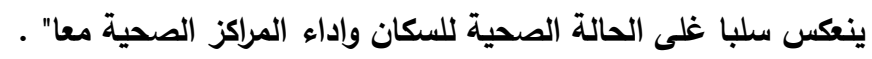

2- زمن الوصول : يتباين زمن الوصول الى المراكز الصحية العامة في احياء المدينة , فقد اظهرت

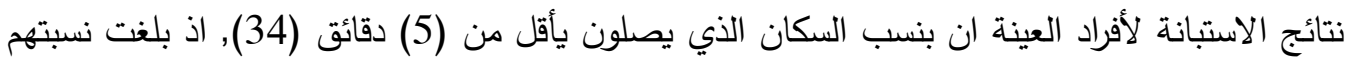

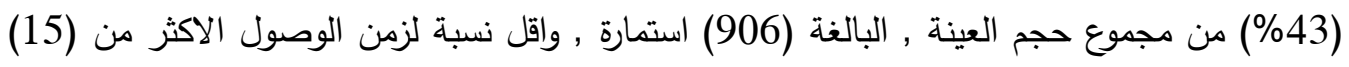

دقيقة بنسبة (11\%) , وهذا يشير الى ان اكثر من الوقت المحدد يتم قطعه.

جدول (15) زمن الوصول لمراكز الصحة العامة لعام (2016/2015)

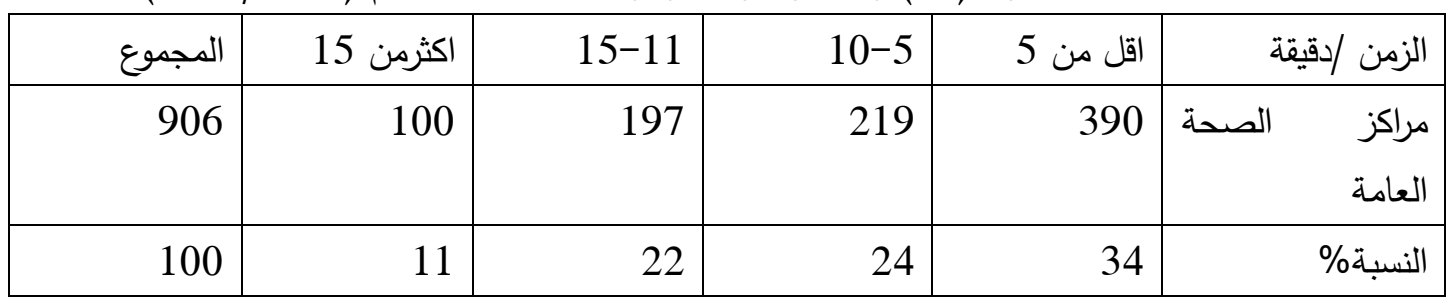

الصدر :. من عمل الباحثين , بالأعتماد على نتائج الاستبانة "وزارة الاسكان والتعمير ,كراس , الدصدر السابق

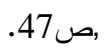




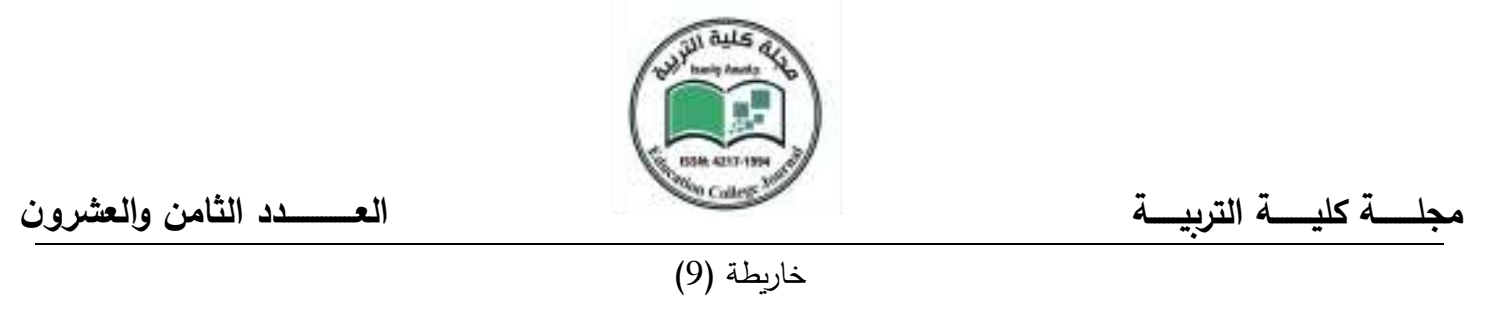

نطاق الخدمة لمراكز الصحة العامة في مدينة الحلة لعام 2016

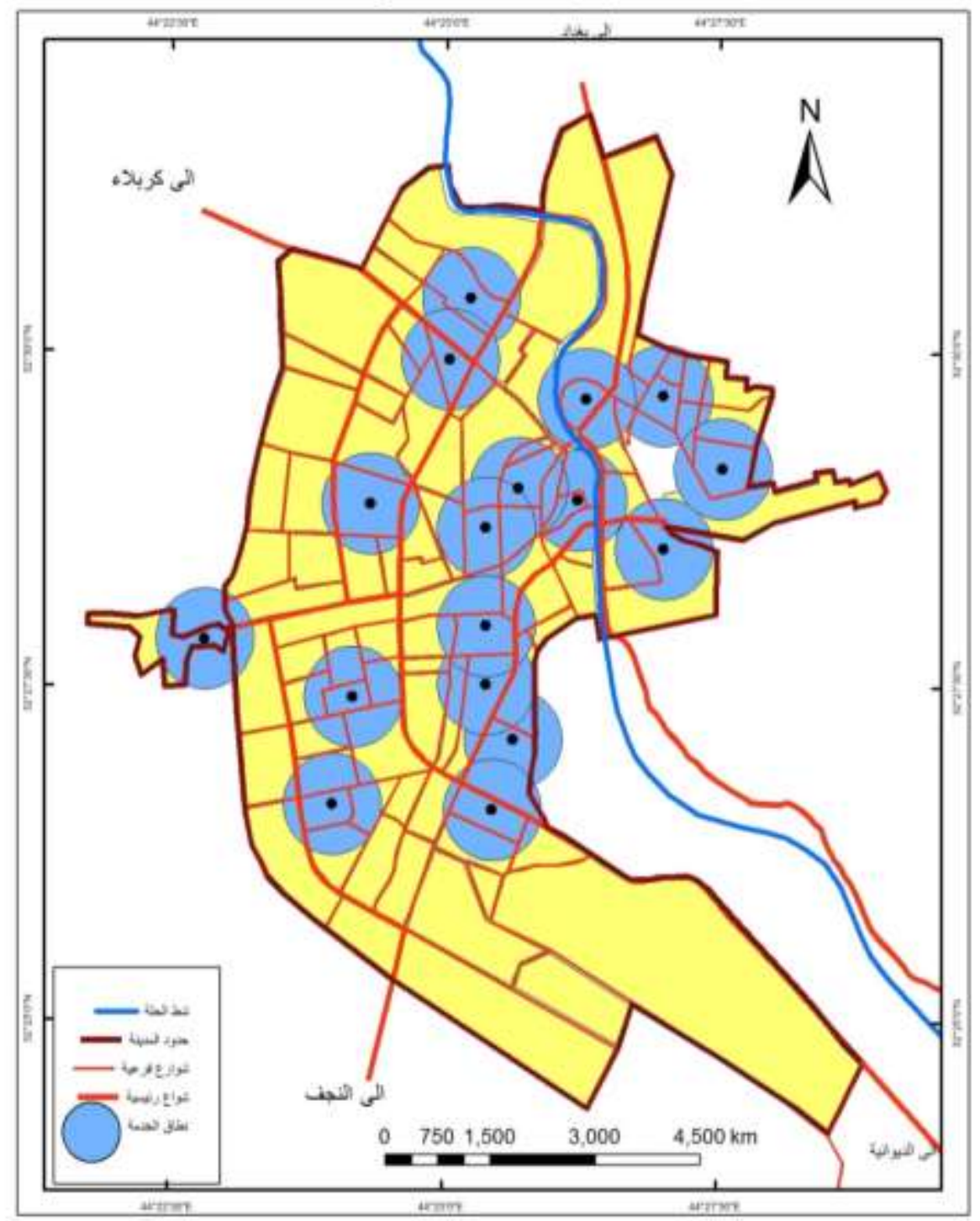

المصدر : من عمل الباحثتين بالاعتماد على معايير وزارة الصحة , معايير خدمة المراكز الصحية , لعام 2011 . 519 
3- تحليل تقنية صلة الجوار : -

ويطلق عليها مسافة الجار الأقرب ( average nearest neighbor distance) وهي من اشهر التحليلات المعروفة في دراسة العلاقات الدكانية لدى الجغرافيين ، وتستعمل لقياس مدى تشتت مواقع النقاط حول بعضها , وتحديد نمط انتشارها في التوزيعات المكانية , اذ يمكن ان تكون عشوائية او وتئية منظمة او مركزة (35), وتكون القيمة محصورة بين (0-149.2) , و وهي أيضا وسيلة لقياس مدى نركز او تشتت المعالم الجغرافية (36) وبلغت قيمة صلة الجنار الأقرب لتوزيع النقاط (مراكز الصحة العامة ) لتساوي (0,74) أي نمط التوزيع غير منتظم وهو اقرب للمتجمع والمسافات بينها غير متساوية , وهذا ما يتطلب اعداد خطط عند تتفيذ بناء مراكز صحية جديدة تعتمد على معيار التوزيع العادل للمراكز , خارطة (6).

4- المعيار الاجتماعي (درجة الرضا ): تعد درجة الرضا عن الخدمة من المؤشرات المهمة وذلك لارتباط

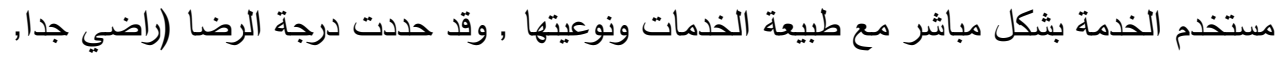
راضي الى حد ما , راضي بدرجة مقبولة , غير راضي الى حد ما , غير راضي جداً ) (37). 
جدول (16)

النسب المئوية لارجة الرضا عن الخدمة لعام ( 2016/2015)

\begin{tabular}{|c|c|c|c|c|c|c|}
\hline المجموع & جيدة جدا بدرجة & ريدة بلرجة & متوسطة بدرجة & قاضي بدرجة & غير راضي & المؤشر \\
\hline 906 & 91 & 160 & 190 & 220 & 245 & عدد الاستمارات \\
\hline 100 & 10 & 18 & 21 & 24 & 27 & النسبة \% \\
\hline
\end{tabular}

المصدر :. من عمل الباحثين , بالأعتماد على نتائج الاستبانة .

ان درجة الرضا عن خدمة المراكز تباينت بين جيدة جداً اذ بلغت عدد الاجابات (75) استمارة , وبنسبة 18\% من مجموع العينة , اما عن عدم الرضا فبلغت الاجابات (90) استمارة وبنسبة (23\%) من حجم العينة .

(ب) المراكز الصحية الوقائية التخصصية :

وتعد هذه المراكز من الاهمية كونها تقدم خدماتها الى سكان المدينة جميعهم بغض النظر عن الموقع والمسافة والزمن اذ تكون على مستوى احياء او قطاع وذلك عن طريق تحويلهم من المراكز الصحية العامة الى هذه المراكز , وعند تطبيق مؤشرات المراكز التخصصية نلاحظ , جدول(17) .

جدول(17)

الحاجة وعدد المراكز التخصصية ومساحتها الكلية في مدينة الحلة لعام 2016

\begin{tabular}{|c|c|c|c|c|c|}
\hline \multicolumn{2}{|c|}{ الحاجة من المراكز التخصصة } & \multirow{2}{*}{ مساحة المراكز الكلية } & \multirow{2}{*}{ عدد المراكز التخصصية } & \multirow{2}{*}{ عدد السكان } & \multirow{2}{*}{ القطاع } \\
\hline المساحة م2 & عدد المراكز & & & & \\
\hline 2,4000 & 2 & I & I & 65038 & الفردوس \\
\hline $2 \curvearrowright 2000$ & 1 & 1500 & 1 & 73518 & الفيحاء \\
\hline $2 \curvearrowright 2000$ & 1 & 3000 & 3 & 160093 & السلام \\
\hline 2,6000 & 3 & 1500 & 1 & 154226 & الفرات والزههور \\
\hline
\end{tabular}

المصدر :. من عمل الباحثين , بالأعتماد على معايير الخدمة للمراكز التخصصية . 
5- المشكلات في المراكز الصحية العامة والتخصصية : اتضح خلال الدراسة وجود عدد من المشكلات

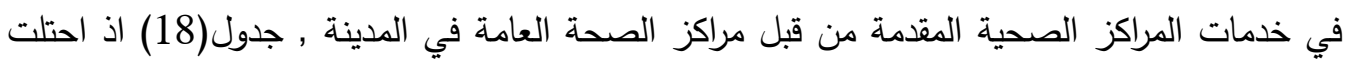
قلة الادوية المرتبة الاولى , وشكلت نسبة بلغت (50\%) , بينما شكلت مشكلة قلة الاطباء نسبة فركات

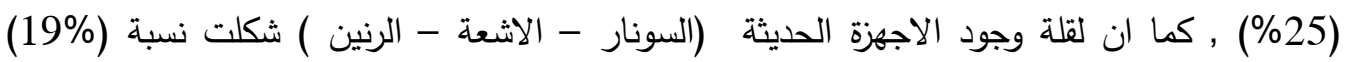
واخيرا وليسراخرا نجد ان مشكلة الكار الادري كان احد المشكلات التي تعاني منها مراكز المدينة ,

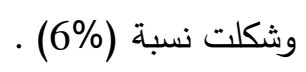

\section{جدول(18)}

المثكلات في المراكز الصحية في المدينة لعام 2016

\begin{tabular}{|c|c|c|}
\hline $\begin{array}{r}\text { نسب التركز } \\
\text { \% }\end{array}$ & عدد الاستمارات & نوع المشكلات \\
\hline 50 & 450 & ق ق قلة الاوية \\
\hline 25 & 231 & قلة الاطباء الاختصاص \\
\hline 19 & 170 & قلة الاجهزة الطبية \\
\hline 6 & 50 & قلتة الكادر الااري \\
\hline 100 & 906 & المجموع \\
\hline
\end{tabular}

المصدر :. من عمل الباحثين , بالأعتماد على استمارة الاستبانة لعام 2016 .

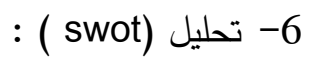

هو اسلوب تحليلي لمعرفة نقاط القوة والضعف في الخدمة , ومعرفة الفرص والتهديدات التي تواجه الخذمة ., ويعتبر من افضل النظم لبناء استراتيجيات الاعمال (خطط طويلة وخطط قصيرة المدى ) ) .

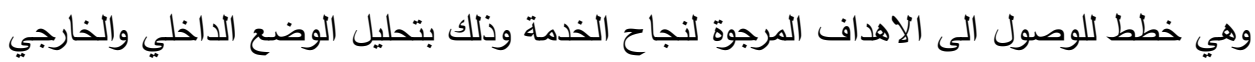
من خلال البنود الاربعة التالية : نقاط القوة , نقاط الضعف الاهدو , الفرص, التهديدات) , وكانت نتائج تحليل

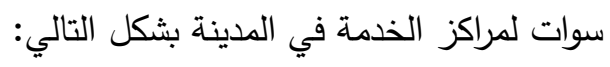




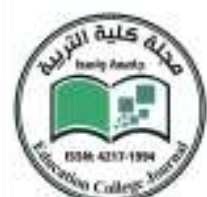

مجلــــة كليـــــة التربيـــة

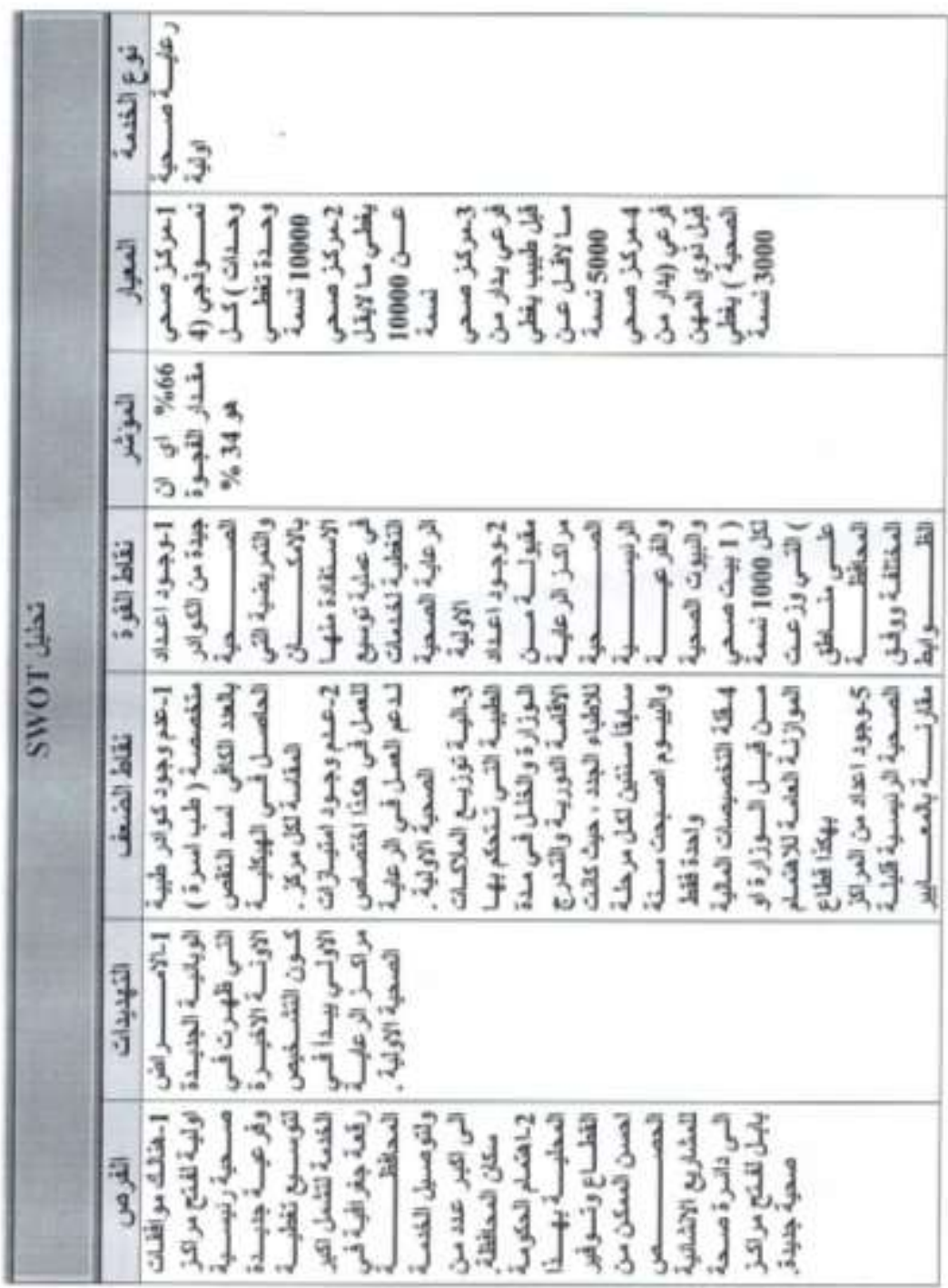




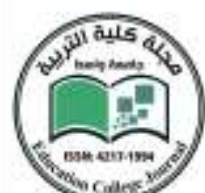

مجلــــة كليـــــة التربيـــة

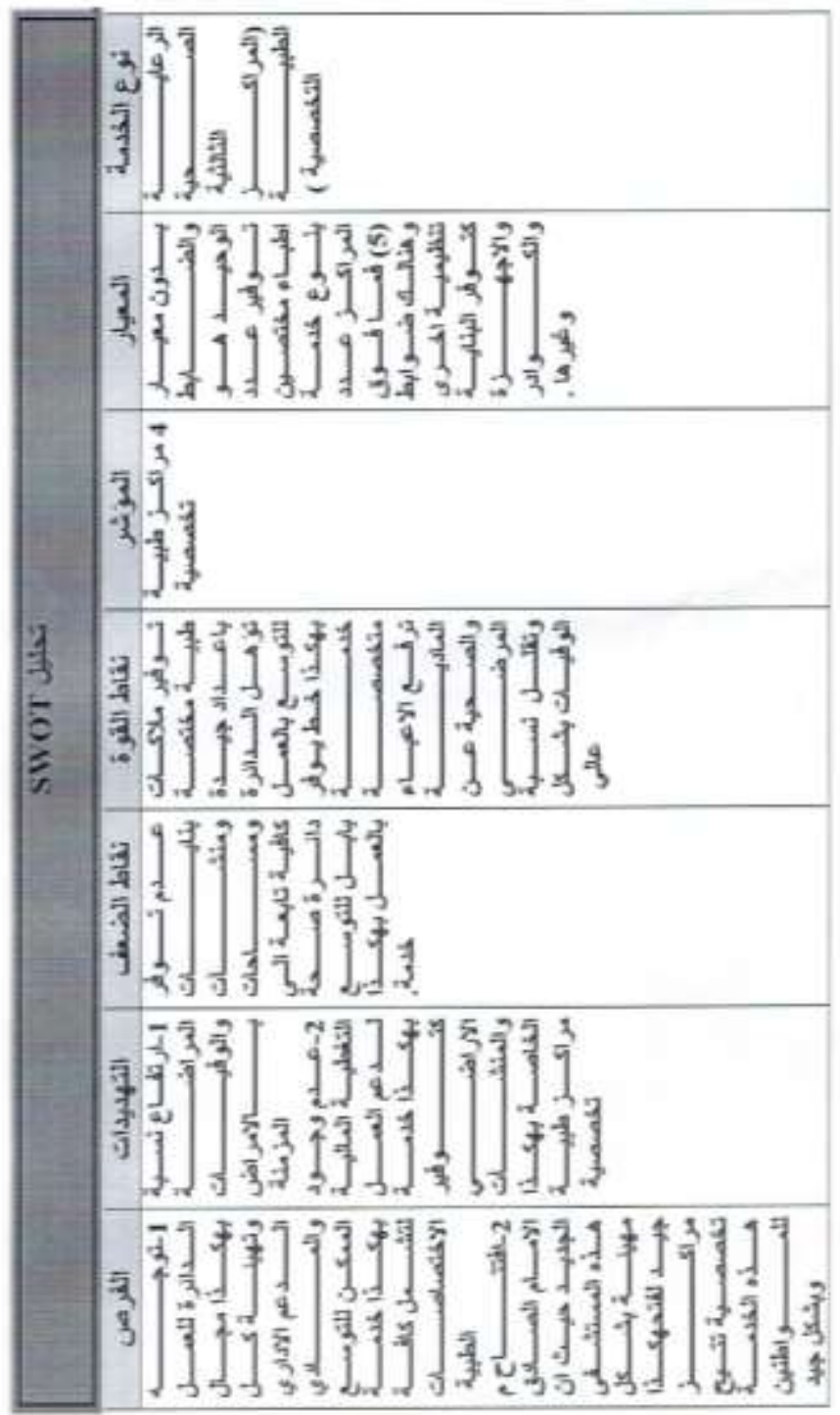


1- اظهرت الاراسة ان هناك عجزا واضحا في عدد المراكز العامة في المدينة على اساس المعيار المحلي مركز لكل (10000) نسمة , بلغ (28)مركزا .

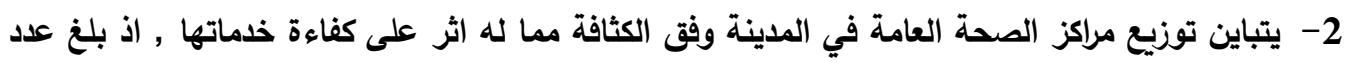

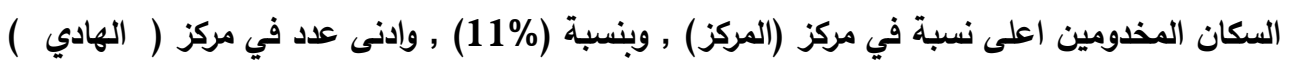

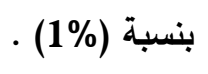

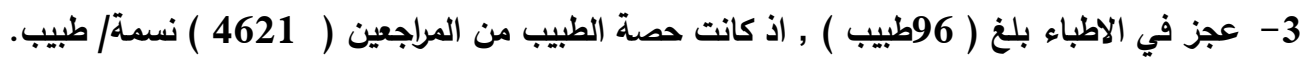
4- عجر في عدد اطباء الاسنان بلغ (146) , اذ كانت حصة طبيب الاسنان من المراجعيين (6077) مراجع

5- كان هناك فائض في عدد الصيادلة اذ انت حصة الصيدلي(11674)نسمة/ للصيدلي

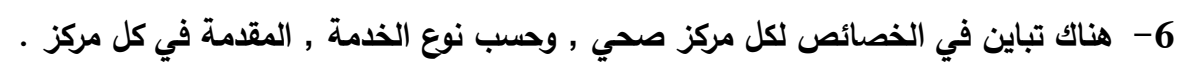

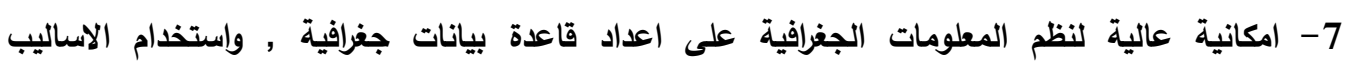

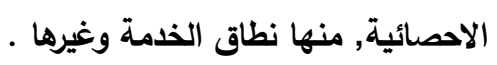
التوصيات : الاحصائه :

1- ضرورة اعادة النظر بصيخ المقارنة بين السكان في اعداد مراكز الصحة العامة في المدينة مما يكفل ضمان نصيب الفرد من الخدمة .

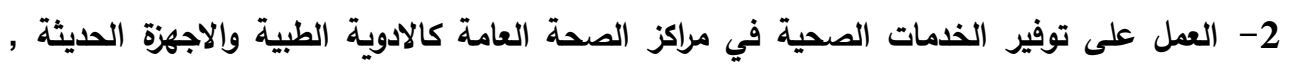
وسيارات الاسعاف , وصالات الطوارئ.

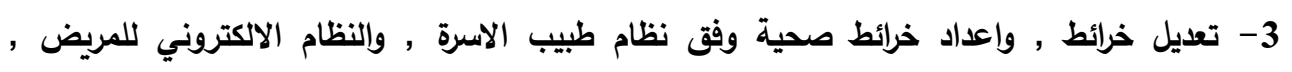

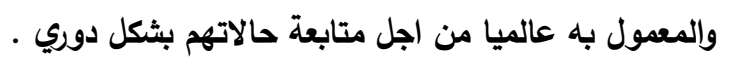

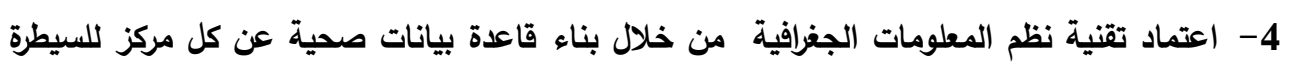
على مناطق الاوبئة وخطر الافات الصحية . 5- متابعة تنفيذ الخدمات الصحية في احياء المدينة الحديثة خصوصا الاحياء العشوائية (الزراعية ) , اذ بلغت (48)حي , وحسب حجم وكثافة السكان . 
1- خالص حسني الاشعب , صباح محمود ,موقولوجية المدينة , وزارة التعليم العالي والبحث العلمي مطبعة جامعة بغداد بيغداد 1983,ص219.

2- ماجدة محمد طاهر , اسس ومعايير الخدمات في المنطقة الصحراوية في العراق هيئة التخطيط

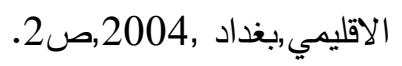

3- عبد السلام رضوان ,حاجات الانسان الاساسية في الوطن العربي ,سلسلة عالم المعرفة ,العدد150

$$
\text { , الكويت , 1990,ص 23. }
$$

4- بيانات مديرية احصاء بابل , بيانات غير متوفرة ,2016.

$$
\text { 5- ملحق (1) استمارة الاستبانة. }
$$

6- زين حسن بدران وايمن سلمان ,الرعاية الصحية الاولية دار المسرة للنشر والتوزيع ,ط1 , عمان

$$
\text { 13ص,2009, }
$$

7- جمهورية العراق , وزارة الصحة ,دائرة الصحة العامة ,ورقة عمل النظام الصحي الكقترح محور

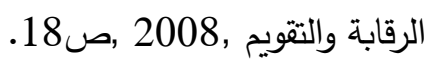

8- رياض كاظم سلمان ,كفاءة التوزيع المكاني للخدمات المجتمعية في مدينة كربلاء ,اطروحة دكتوراة ,

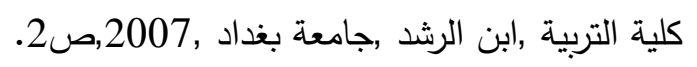

Pride \& fervor<the nature \& importance of services new york 2000, peg32. -9 10- خلف حسين علي الدليمي , تخطيط الخدمات المجمعية والبنية التحتية "الس ومعايير و

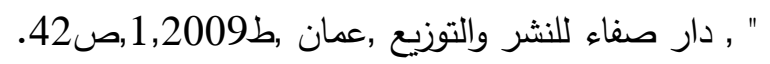

11- نظم المعلومات الجغرافية ,المؤسسة العامة للتعليم والتتريب المهني , الادارة لتطوير

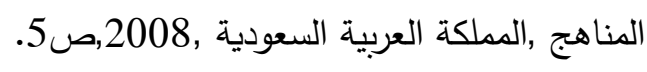

B.Ayeni,conepts and techniques in urban ANaLysis, Groom Helm ,

London.1979.p, 105.

صلاح محمد الجنابي ,جغرافية الحضر ,اسس وتطبيقات ,جامعة الموصل ,دار الكتب

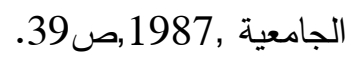




$$
\text { york ,1969,P180. }
$$

حسين السيد ابو العينين, اصول الجغرافية المناخية ,ط1,دار الجامعة للطباعة والنشر ,

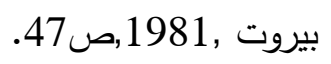

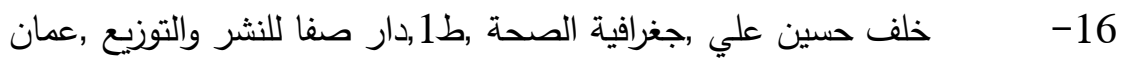

$$
\text { 2009, 200,ص247, }
$$

جاسم شعلان الغزالي ,الكفاءة الوظيفية للدحلات السكنية لمدينة الحلة رسالة ماجستير

غير منشورة مركز التخطيط الحضري .

$$
\text { -18 }
$$

علي صاحب الموسوي ,العلاقات المكانية بين الخصائص المناخية في العراق وأختيار

اسلوب وطريقة الري المناسبة,اطروحة دكتوراة ,غير منشورة ,جامعة بغداد, كلية الاداب

$$
\text { 133.1996, }
$$

عبد الغني ,جميل سلطان ,الجو وعناصره وتقلباته ,الجمهورية العراقية وزارة الثقافة

$$
\text { والاعلام ,1985,ص125. }
$$

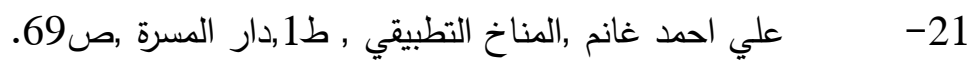

22- الح فليح حسن الهيتي , تطور الوظيفة السكنية لمدينة بغداد الكبرى (1957-1950)

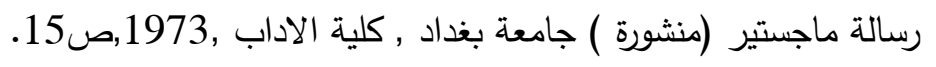

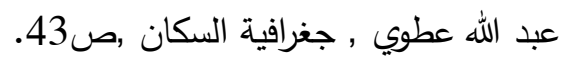

Arhur.G.Barry.B.models of Spatial prproach to the study of point

,line and areapattren. Combra dge U.London .N.Y.1978,p.16.

محمد بن مفرج القحطاني , التتمية المكانية لمراكز الرعاية الصحية الاولية في منطقة احد

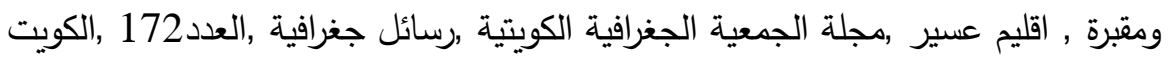

$$
\text { .403 1994, }
$$

زهير حاتم خماس , التوزيع المكاني للمستشفيات الاهلية في مدينة بغداد رسالة ماجستير

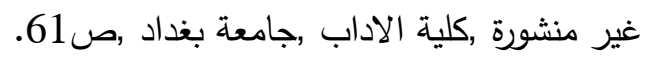




$$
\begin{array}{rr}
-27 & -27 \\
\hline
\end{array}
$$

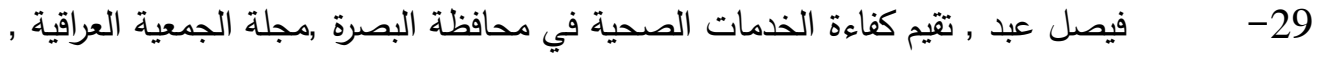

$$
\text { العدد 43,بغداد 2000,ص243. }
$$

30 - محمد جبر وعبد الجبار , وعبد العباس , كراس الرعاية الصحية الاولية ,وزارة الصحة

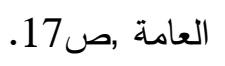

31- رويبر اوزيل ,فن تخطيط المدن, ترجمة بهيج شعبان ,منشورات عويدات بيروت

$$
\text { .47, 1974, }
$$

-32 - معايير الاسكان الحضري,وزارة الاعمار والاسكان, شعبة الدراسات,تشرين الاول

$$
\text { 11, 2010, }
$$

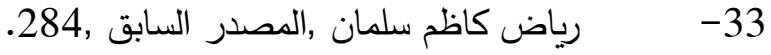

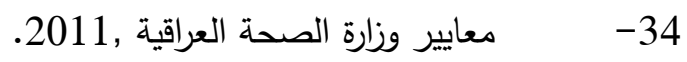

Helen . h \&disk. M. gis ,as tool for road and tran sportaion -35 statistics working ,paper no 22, work session on gis,Brghton uk .p.22-25.

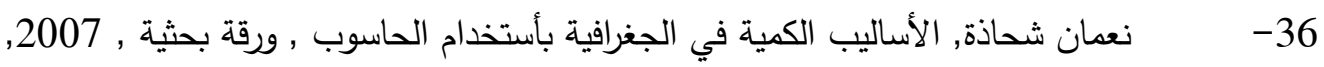
ص195.

37- وزارة التخطيط والتعاون الانمائي ,الجهاز المركزي للاحصاء والمعلومات ,مسح احوال

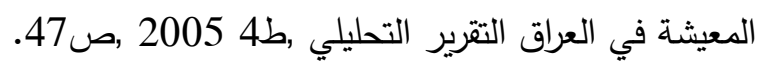

